\title{
Methodological Quality of Randomized Clinical Trials of Respiratory Physiotherapy in Coronary Artery Bypass Grafting Patients in the Intensive Care Unit: a Systematic Review
}

Jaqueline Lorscheitter ${ }^{1}$, PT, MSc; Cinara Stein ${ }^{1,2,3}$, PT, MSc, PhD; Rodrigo Della Méa Plentz' ${ }^{1}$ PT, DSc

DOI: $10.21470 / 1678-9741-2017-0014$

\section{Abstract}

Objective: To assess methodological quality of the randomized controlled trials of physiotherapy in patients undergoing coronary artery bypass grafting in the intensive care unit.

Methods: The studies published until May 2015, in MEDLINE, Cochrane and PEDro were included. The primary outcome extracted was proper filling of the Cochrane Collaboration's tool's items and the secondary was suitability to the requirements of the CONSORT Statement and its extension.

Results: From 807 studies identified, 39 were included. Most at
CONSORT items showed a better adequacy after the statement's publication. Studies with positive outcomes presented better methodological quality.

Conclusion: The methodological quality of the studies has been improving over the years. However, many aspects can still be better designed.

Keywords: Physical Therapy Modalities. Thoracic Surgery. Cardiac Surgical Procedures. Methodology. Systematic Review. Review Literature as Topic. Intensive Care Unit.

\begin{tabular}{|c|c|}
\hline CABG & $=$ Coronary artery bypass grafting \\
\hline FEV1 & $=$ Forced expiratory volume in one second \\
\hline ICU & $=$ Intensive care unit \\
\hline $\mathrm{PaO}_{2}$ & $=$ Partial pressure of oxygen \\
\hline PEDro & = Physiotherapy evidence database \\
\hline RCT & $=$ Randomized clinical trials \\
\hline
\end{tabular}

\section{INTRODUCTION}

The large amount of publications in health care makes professionals have difficulty to stay up to date. Moreover, a great part of the available information does not come from studies with adequate methodological quality, what makes them of little clinical relevance. Incomplete or inadequate publication of information on the study planning and driving affects the identification of possible methodological errors, also hampering the use of its findings by the interested parties, since they cannot critically assess its clinical applicability ${ }^{[1,2]}$.

Even though randomized clinical trials (RCT) are gold standard for the assessment of health interventions, this type of study is also prone to bias whether due to researchers arbitrariness when selecting the sample and gauging the analyzed variables, or due to the difficulty of controlling other factors that may influence the clinical outcome. Bias or systematic error can be defined as any tendentiousness in the collection, analysis, interpretation, publication or revision of data, which induces conclusions that systematically tend to distance themselves from the truth ${ }^{[3]}$.

In phase I of cardiac rehabilitation, physiotherapy has an increasingly important role in contributing to the patients return to their social and professional activities in the best possible
'Graduate Program in Health Sciences, Universidade Federal de Ciências da Saúde de Porto Alegre (UFCSPA), Porto Alegre, RS, Brazil.

2Laboratory of Clinical Investigation, Instituto de Cardiologia do Rio Grande do Sul (IC), Porto Alegre, RS, Brazil.

3Fundação Universidade de Cardiologia (FUC), Porto Alegre, RS, Brazil.

This study was carried out at Universidade Federal de Ciências da Saúde de Porto Alegre, RS, Brazil.

No financial support

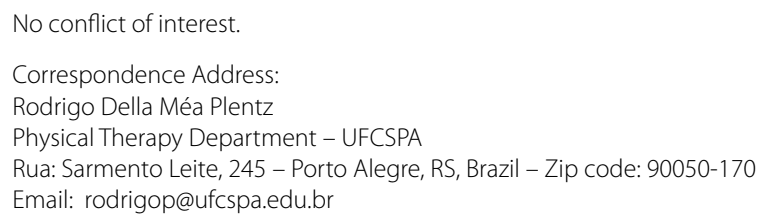
Article accepted on May 11 $11^{\text {th }}, 2017$. 
clinical conditions, thus improving the quality of life ${ }^{[4]}$. In the early postoperative period after a coronary artery bypass grafting $(C A B G)$, respiratory physiotherapy has been widely requested in order to reverse or minimize postoperative pulmonary complications $s^{[5]}$. Techniques that can improve respiratory mechanics, lung re-expansion and bronchial hygiene are applied, contributing to the patients proper ventilation ${ }^{[6]}$.

Numerous studies over the past decade have documented that physiotherapists are in favor of evidence-based medicine and recognize the importance of using research results to achieve a more scientific-based clinical practice. Therefore, the number of publications that consistently support the best physiotherapy procedures to be followed have been increasing ${ }^{[7]}$. Assessments of physiotherapy intervention studies demonstrate an upward curve in relation to the enrichment of the methodological quality over the past decades ${ }^{[8-11]}$. However, there is still great potential for improvement in their elaboration and development.

It should be noted that no evidence can be observed on the methodological quality of RCT of physiotherapy intervention on CABG postoperative patients in the intensive care unit (ICU). Therefore, this research is needed since the fulfillment or not of the criteria for a correct development of this research design can influence the results. Also, complementarily, the dissemination of these data will stimulate further research to be developed with a superior methodological quality, showing the main points that should be better outlined and planned. It will then be possible to obtain greater benefits, as well as improved outcomes for critical patients in daily clinical practice. It should be noted that there is no evidence on the methodological quality of RCT of physiotherapy intervention on CABG postoperative patients in the Intensive Care Unit (ICU).

\section{METHODS}

This review was conducted in accordance with the recommendations proposed by the Cochrane Collaboration and the Preferred Reporting Items for Systematic Review and Meta-analyses: The PRISMA ${ }^{[12,13]}$. The studies methodological quality was evaluated using the Cochrane Collaboration's tool for assessing risk of bias ${ }^{[12]}$, and the correct description of the RCT's items was evaluated using the CONSORT Statement ${ }^{[14]}$ and its extension for clinical trials of nonpharmacologic treatment interventions ${ }^{[15]}$. When certain items were not applicable to all studies (as in the case of the evaluation of multicenter studies), they were considered as adequate.

\section{Eligibility Criteria}

Studies designed as RCT's, with respiratory physiotherapy intervention, associated or not with neuromusculoskeletal physiotherapy, in postoperative patients of CABG in the ICU were included. Studies whose intervention also happened in the preoperative period were included as well. The following were ineligible for inclusion in the review: studies whose patients had undergone another associated surgery and studies that did not contain terms related to physiotherapy and its synonyms (physiotherapy, physical therapy, physiotherapists, physical therapists, and respiratory therapists) anywhere in the paper.

\section{Search Strategies}

The search was conducted in the following electronic databases (from inception to May 26, 2015): MEDLINE (via PubMed), Central Register of Controlled Trials (Cochrane CENTRAL) and Physiotherapy Evidence Database (PEDro). Additionally, manual search was conducted in the references of published papers. The search terms used were "Coronary Artery Bypass Grafting", terms related to respiratory physiotherapy interventions, such as "breathing exercises" and "respiratory muscle training", and a word sequence with high sensitivity for the search of randomized RCT described by Robinson \& Dickersin ${ }^{[16]}$. Papers not published in English were excluded. The full search strategy used in the PubMed, which was adjusted for the search in the other databases, is shown in Table 1.

\section{Study Selection and Data Extraction}

The selection of studies was carried out by two reviewers (J.L. and C.S.), independently, in two stages: I - selection of studies by reading the titles and abstracts; $\|$ - full analysis of papers selected in Phase I. Papers were included in accordance with the eligibility criteria specified previously. In case of disagreement on the paper's inclusion and with no consensus between the reviewers, a third reviewer (R.P.) was consulted. The primary outcome extracted was proper fulfilling of the Cochrane Collaboration's tool's items, and the secondary outcome extracted was suitability to the requirements of the CONSORT Statement and its extension. The data extraction was performed separately and independently by both reviewers (J.L. and C.S.) and crosschecked. Disagreements regarding the data extraction were solved by a third author (R.P.). Three standardized forms were used, which contained: the 25 items of the CONSORT checklist, the 7 items of the Cochrane Collaboration's tool for assessing risk of bias, and the 16 items of the CONSORT checklist extension for clinical trials of non-pharmacologic treatment interventions. For the CONSORT Statement items, the concept of "adequate" or "inadequate" was assigned, according to the description or not of each item in the checklist. The Cochrane Collaboration's tool's items without a clear description were classified with the word "no" or "not report". In the case of missing data, the authors were contacted by e-mail at least twice. The study was excluded if the data were still insufficient after this process.

\section{Data Analysis}

The results are going to be descriptively displayed (frequency and percentage).

\section{RESULTS}

\section{Description of Studies}

The search strategy identified 807 potentially relevant studies, adding a further 17 studies drawn from the reference lists. Subsequently, 172 duplicates were discarded and 565 irrelevant studies were excluded. Among the 87 resulting records, two were excluded for not having been published in English, 25 had not described a term related to physiotherapy and its synonyms, 
Table 1. Strategy used for PubMed.

\begin{tabular}{|c|c|}
\hline \#1 & $\begin{array}{l}\text { "Coronary Artery Bypass"[Mesh] OR "Coronary Artery Bypass Grafting" OR "Coronary Artery Bypass Surgery" OR "Bypass, } \\
\text { Coronary Artery" OR "Artery Bypass, Coronary" OR "Artery Bypasses, Coronary" OR "Bypasses, Coronary Artery" OR } \\
\text { "Coronary Artery Bypasses" OR "Aortocoronary Bypass" OR "Aortocoronary Bypasses" OR "Bypass, Aortocoronary" OR } \\
\text { "Bypasses, Aortocoronary" OR "Bypass Surgery, Coronary Artery" "Myocardial Revascularization"[Mesh] OR "Myocardial } \\
\text { Revascularizations" OR "Revascularization, Myocardial" OR "Revascularizations, Myocardial" OR "Internal Mammary Artery } \\
\text { Implantation" }\end{array}$ \\
\hline \#2 & $\begin{array}{l}\text { "breathing exercises" OR "Intermittent Positive Pressure Breathing" OR "continuous positive airway pressure" OR } \\
\text { "weaning from mechanical ventilation" OR "mechanical ventilation" OR "noninvasive ventilation" OR "breathing exercises" } \\
\text { OR "Exercise, Breathing" OR "Respiratory Muscle Training" OR "Muscle Training, Respiratory" OR "Training, Respiratory } \\
\text { Muscle" OR "Breathing, Intermittent Positive Pressure" OR "Intermittent Positive Pressure Breathing" OR "Positive Pressure } \\
\text { Breathing, Intermittent" OR "Intermittent Positive Pressure Breathing (IPPB) "OR "Inspiratory Positive Pressure Breathing" OR } \\
\text { "Breathing, Inspiratory Positive Pressure" OR "Inspiratory Positive Pressure Breathing" OR "Positive Pressure Breathing" OR } \\
\text { "Inspiratory" OR "IPPB" OR "CPAP Ventilation" OR "Ventilation, CPAP" OR "Biphasic Continuous Positive Airway Pressure" OR } \\
\text { "Bilevel Continuous Positive Airway Pressure" OR "Nasal Continuous Positive Airway Pressure" OR "nCPAP Ventilation" OR } \\
\text { "Ventilation, nCPAP" OR "Airway Pressure Release Ventilation" OR "APRV Ventilation Mode" OR "APRVVentilation Modes" OR } \\
\text { "Ventilation Mode, APRV" OR "Ventilation Modes, APRV" OR "Respiration, Artificial" OR "Artificial Respiration" OR "Artificial } \\
\text { Respirations" OR "Respirations, Artificial" OR "Ventilation, Mechanical" OR "Mechanical Ventilations" OR "Ventilations, } \\
\text { Mechanical" OR "Mechanical Ventilation" OR "Noninvasive Ventilations" OR "Ventilation, Noninvasive" OR "Ventilations, } \\
\text { Noninvasive" OR "Non-Invasive Ventilation" OR "Non-Invasive Ventilations" OR "Ventilation, Non-Invasive" OR "Ventilations, } \\
\text { Non-Invasive" OR "Non Invasive Ventilation" OR "Non Invasive Ventilations" OR "Ventilation, Non Invasive" OR "Ventilations, } \\
\text { Non Invasive" }\end{array}$ \\
\hline \#3 & $\begin{array}{l}\text { randomized controlled trial[pt] OR controlled clinical trial[pt] OR randomized controlled trials[mh] OR randomallocation[mh] } \\
\text { OR double-blind method[mh] OR single-blind method[mh] OR clinical trial[pt] OR clinical trials[mh] OR ("clinical trial"[tw]) } \\
\text { OR ((singl*[tw] OR doubl*[tw] OR trebl*[tw] OR tripl*[tw]) AND (mask*[tw] OR blind*[tw])) OR ("latinsquare"[tw]) OR } \\
\text { placebos[mh] OR placebo*[tw] ORrandom*[w] OR research design[mh:noexp] OR follow-up studies[mh] OR prospective } \\
\text { studies[mh] OR cross-over studies[mh] OR control*[tw] OR prospectiv*[tw] OR volunteer*[tw]) NOT (animal[mh] NOT } \\
\text { human[mh]). }\end{array}$ \\
\hline
\end{tabular}

three were not RCT's, seven were not with postoperative patients of CABG or had other associated surgery, two studies had not been performed in the ICU and nine studies were not available. Figure 1 shows the study flowchart.

Among the 39 studies included ${ }^{[17-55]}, 41.02 \%(n=16)$ were conducted in Brazil, 56.41\% ( $n=22)$ were published between 2000 and 2010, and only $12.82 \%(n=5)$ were published in journals specialized in physiotherapy. In relation to the sample, in $33.33 \%$ $(n=13)$ of the studies the number of patients was higher than 70 , in $58.97 \%(n=23)$ the average age was of over 60 years, and in $84.61 \%(n=33)$ of the studies more than half of the sample consisted of males. The treatment was provided only in the postoperative period in $69.23 \%(n=27)$ of the studies, and in $51.28 \%(n=20)$ a patients were monitored until discharge.

The most widely used techniques were re-expansive ventilatory exercises (56.41\%), ventilatory exercises for bronchial hygiene (48.71\%) and non-invasive mechanical ventilation (41.02\%). There was an association of techniques in $69.23 \%$ $(n=27)$ of the studies.

The most researched outcomes were atelectasis (48.71\%), forced expiratory volume in one second (FEV1) (41.02\%), invasive mechanical ventilation time (35.89\%) and partial pressure of oxygen $\left(\mathrm{PaO}_{2}\right)$ (35.89\%). The Table 2 shows the characterization studies.

\section{CONSORT Statement}

According to the CONSORT assessment, the three items that were best and worst described were, respectively: introduction (100\%), interventions (100\%), and outcomes and estimation (100\%); allocation concealment (7.69\%), ancillary analysis (7.69\%), and generalizability (2.56\%) (Table 3). The CONSORT extension (Table 4) presented as the best described items: participants (100\%), interventions (100\%), and components of the interventions (100\%). On the other hand, the lowest scoring items were title and abstract (0\%), assessment of adherence with the protocol (0\%), and concealment method (5.12\%).

Seven studies conducted before the CONSORT publication were identified. When compared to other studies, the items introduction, interventions, results, outcomes and estimation, interpretation, and protocol remained equally adequate. The correct description of the items blinding and statistical methods decreased $41.96 \%$ and $6.25 \%$ respectively in the studies published after the CONSORT. All of the 17 remaining items were described more frequently after the CONSORT publication, as follows: title and abstract (increase of 10.72\%), design (increase of $26.34 \%$ ), participants (increase of $52.68 \%$ ), sample size (no description of this item was found in any of the studies published previously to the CONSORT, but it was described in $46.87 \%$ of 


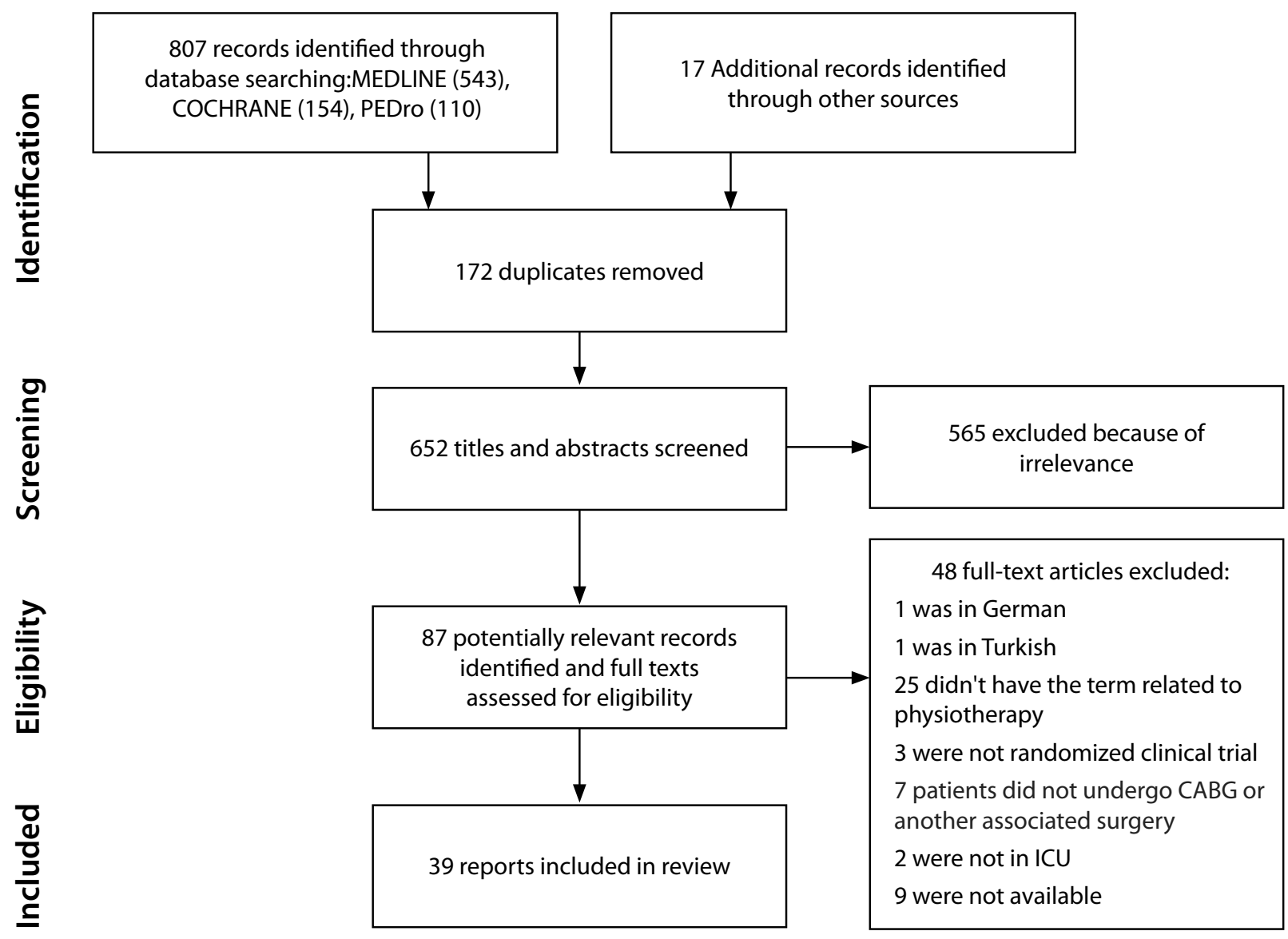

Fig. 1 - Study flowchart.

$C A B G=$ coronary artery bypass grafting; $/ C U=$ intensive care unit

the studies after it), random sequence generation (increase of 30.80\%), allocation concealment (no description of this item was found in any of the studies published previously to the CONSORT, but it was described in $9.37 \%$ of the studies after it), allocation implementation (no description of this item was found in any of the studies published previously to the CONSORT, but it was described in $12.50 \%$ of the studies after it), participant flow diagram (increase of 6.69\%), recruitment (increase of 15.18\%), characteristics (increase of 1.79\%), numbers analyzed (increase of $35.27 \%$ ), ancillary analyses (no description of this item was found in any of the studies published previously to the CONSORT, but it was described in $9.37 \%$ of the studies after it), harms (increase of $4.47 \%$ ), limitations (no description of this item was found in any of the studies published previously to the CONSORT, but it was described in $50 \%$ of the studies after it), generalizability (no description of this item was found in any of the studies published previously to the CONSORT, but it was described in $3.12 \%$ of the studies after it), registration (no description of this item was found in any of the studies published previously to the
CONSORT, but it was described in $6.25 \%$ of the studies after it) and funding (increase of 1.34\%). The item "protocol" was not appropriate according to the CONSORT requirements in any of the studies evaluated (Figure 2).

Among the 39 studies, 27 presented its final outcomes as positive and 12 as negative with the proposed treatment. Regarding the CONSORT checklist's Methods section, when evaluated separately in accordance with the outcome, all items showed to have equal or better methodological quality in the studies with positive outcomes, except for the Statistical Methods item (Figure 3).

\section{Risk of Bias}

Regarding the assessment of the Cochrane Collaboration's tool for risk of bias, description of losses and exclusions in $66.66 \%$ of the studies, proper random sequence generation in $51.28 \%$, blinding of outcome assessors in 46.15\%, intention-to-treat analysis in 12.82\%, and allocation concealment and blinding of patients and investigators in $7.69 \%$ could be noted (Table 5). 
Table 2. Characteristics of studies included in systematic review.

\begin{tabular}{|c|c|c|c|c|c|c|c|}
\hline Author, Year & Intervention & Comparator & $\stackrel{\stackrel{N}{N}}{(I G / C G)}$ & $\begin{array}{c}\text { Mean Age } \\
\pm \text { SD (IG/CG) }\end{array}$ & $\begin{array}{l}\text { Male } \\
(\mathrm{IG} / \mathrm{CG})\end{array}$ & Protocol & Conclusion \\
\hline $\begin{array}{c}\text { Al Jaaly et al. }{ }^{[17]}, \\
2013\end{array}$ & $\begin{array}{c}\text { BPAP, RVE, VEBH, } \\
\text { EM, IS, NBL }\end{array}$ & $\begin{array}{l}\text { RVE, VEBH, } \\
\text { EM, IS, NBL }\end{array}$ & $66 / 63$ & $\begin{array}{c}65.7 \pm 10.7 / \\
69.4 \pm 8.86\end{array}$ & $\begin{array}{c}\text { Not } \\
\text { reported }\end{array}$ & $\begin{array}{c}\text { IG: Usual care and BPAP } \\
\text { during the first } 24 \text { hours after } \\
\text { extubation } \\
\text { CG: usual care alone twice per } \\
\text { day for the first } 2 \text { to } 3 \text { days after } \\
\text { surgery } \\
\text { Outcomes: atelectasis, FEV1, } \\
\text { ICU days, days of hospitalization, } \\
\mathrm{PaCO}_{2}\end{array}$ & $\begin{array}{l}\text { Among patients undergoing } \\
\text { elective coronary artery bypass } \\
\text { grafting, the use of BPAP at } \\
\text { extubation reduced the recovery } \\
\text { time. Supported by trained staff, } \\
\text { more than } 75 \% \text { of all patients } \\
\text { allocated to BPAP tolerated it for } \\
\text { more than } 10 \text { hours }\end{array}$ \\
\hline $\begin{array}{c}\text { Barros et al. }{ }^{[18]} \\
2010\end{array}$ & IMT, TM, PD, AT & TM, PD, TS & $23 / 15$ & $\begin{array}{c}62.1 \pm 8.1 / \\
67 \pm 7.1\end{array}$ & $19 / 6$ & $\begin{array}{c}\text { IG: conventional physiotherapy } \\
\text { and IMT, with three sets of ten } \\
\text { repetitions, once a day, with } \\
40 \% \text { of the } \mathrm{PI}_{\max } \\
\text { CG: Conventional physiotherapy } \\
\text { with four sets of six cycles of } \\
\text { vibrocompression associated with } \\
\text { postural drainage and aspiration } \\
\text { where necessary, twice a day } \\
\text { Outcomes: PI } \mathrm{I}_{\text {max, }} \text { PE } E_{\max } \\
\text { Dyspnea, pain, PEF, CV } \\
\end{array}$ & $\begin{array}{l}\text { There is loss of respiratory } \\
\text { muscle strength in patients } \\
\text { undergoing coronary } \\
\text { revascularization. The IMT, } \\
\text { performed in the postoperative } \\
\text { period, was effective in restoring } \\
\text { the following parameters: } \\
\mathrm{PI}_{\text {max }} \mathrm{PE}_{\text {max }} \text { PEF and CV in this } \\
\text { population }\end{array}$ \\
\hline $\begin{array}{c}\text { Blattner et al.[19], } \\
2008\end{array}$ & $\mathrm{MH}, \mathrm{TS}$ & TS & $28 / 27$ & $\begin{array}{c}55.6 \pm 8.7 / \\
57.6 \pm 4.9\end{array}$ & $16 / 17$ & $\begin{array}{l}\text { IG: Twenty minutes } \mathrm{MH} \text { with } \\
\text { flow of } 15 \mathrm{l} / \mathrm{m} \text { and expiratory } \\
\text { pressure } 10 \mathrm{cmH}_{2} \mathrm{O} \text {, often } 18 \text { to } \\
30 \mathrm{rpm} \text { and TS } \\
\text { CG:TS } \\
\text { Outcomes: atelectasis, pleural } \\
\text { effusion, consolidation, } \mathrm{PaO}_{2} \text {, } \\
\text { Cstat, IMV time, days of } \\
\text { hospitalization }\end{array}$ & $\begin{array}{l}\text { The group that received early MH } \\
\text { had markedly better oxygenation } \\
\text { and static compliance as well as } \\
\text { shorter mechanical ventilation } \\
\text { times than the control group. } \\
\text { The length of hospital stay and } \\
\text { incidence of postoperative } \\
\text { pulmonary complications were } \\
\text { similar in the two groups }\end{array}$ \\
\hline $\begin{array}{c}\text { Borges et al[20] } \\
2013\end{array}$ & $\begin{array}{c}\text { WP with PEEP }(5 \\
\left.\mathrm{CmH}_{2} \mathrm{O}\right)\end{array}$ & $\begin{array}{l}\text { WP with PEEP } \\
\left(8 \mathrm{cmH}_{2} \mathrm{O}\right) / \\
\text { WP with PEEP } \\
\left(10 \mathrm{cmH}_{2} \mathrm{O}\right)\end{array}$ & $\begin{array}{c}44 / 47 \\
/ 45\end{array}$ & $\begin{array}{c}20<60>24 / \\
22<60>25 / \\
19<60>26\end{array}$ & $\begin{array}{c}29 / 32 \\
/ 35\end{array}$ & $\begin{array}{l}\text { IG: PEEP } 5 \mathrm{cmH}_{2} \mathrm{O} \text { after ICU } \\
\text { admission and extubation when } \\
\text { met clinical conditions } \\
\text { CG: PEEP } 8 \mathrm{cmH}_{2} \mathrm{O} \text { after ICU } \\
\text { admission and extubation when } \\
\text { met clinical conditions } \\
\text { CG: PEEP } 10 \mathrm{cmH}_{2} \mathrm{O} \text { after ICU } \\
\text { admission and extubation when } \\
\text { met clinical conditions } \\
\text { Outcomes: ventilatory } \\
\text { mechanics, pulmonary shunt, } \\
\text { oxygenation index }\end{array}$ & $\begin{array}{l}\text { Higher levels of positive end- } \\
\text { expiratory pressure in immediate } \\
\text { postoperative period of coronary } \\
\text { artery bypass grafting improved } \\
\text { pulmonary compliance values } \\
\text { and increased oxygenation } \\
\text { indexes, resulting in lower } \\
\text { frequency of hypoxemia }\end{array}$ \\
\hline $\begin{array}{l}\text { Borghi-Silva et } \\
\text { al. }{ }^{[21]}, 2005\end{array}$ & $\begin{array}{c}\text { PEP, TM, } \\
\text { TS,VEBH, RVE, } \\
\text { EULL, AM, LA }\end{array}$ & $\begin{array}{l}\text { TM, TS, VEBH, } \\
\text { RVE, EE, EULL, } \\
\text { AM, LA }\end{array}$ & $8 / 16$ & $\begin{array}{l}59.9 \pm 9.8 / \\
55.9 \pm 11.9\end{array}$ & $\begin{array}{c}\text { Not } \\
\text { reported }\end{array}$ & $\begin{array}{c}\text { IG: two daily sessions of about } \\
40 \text { minutes. TM, TS, VEBH, EE, } \\
\text { AM, LA. PEP through facial mask } \\
\text { with PEEP } 10 \mathrm{cmH}_{2} \mathrm{O} \\
\text { CG: two daily sessions of about } \\
40 \text { minutes. TM, TS, VEBH, EE, } \\
\text { AM, LA } \\
\text { Outcomes: } V C, F V C \text {, length of } \\
\text { stay, } \mathrm{PI}_{\text {max }}, \mathrm{PE}_{\max }\end{array}$ & $\begin{array}{l}\text { These data suggest that cardiac } \\
\text { surgery produces a reduction } \\
\text { in inspiratory muscle strength, } \\
\text { pulmonary volume, and flow. } \\
\text { The association of positive } \\
\text { expiratory pressure with } \\
\text { physiotherapy intervention was } \\
\text { more efficient in minimizing } \\
\text { these changes, in comparison to } \\
\text { the physiotherapy intervention } \\
\text { alone. However, in both groups, } \\
\text { the pulmonary volumes were } \\
\text { not completely reestablished } \\
\text { by the fifth postoperative day, } \\
\text { and it was necessary to continue } \\
\text { the treatment after hospital } \\
\text { convalescence }\end{array}$ \\
\hline
\end{tabular}




\begin{tabular}{|c|c|c|c|c|c|c|c|}
\hline $\begin{array}{l}\text { Castellana et } \\
\text { al. }[22], 2003\end{array}$ & $\begin{array}{l}\text { WP with VC- } \\
\text { CMV }\end{array}$ & $\begin{array}{l}\text { WP with PC- } \\
\text { CMV }\end{array}$ & $32 / 29$ & $65 \pm 7 / 64 \pm 11$ & $\begin{array}{l}\text { Not } \\
\text { reported }\end{array}$ & $\begin{array}{l}\text { IG: IMV in the } \mathrm{VC}-\mathrm{CMV} \text { mode } \\
\text { with volume of } 7 \mathrm{ml} / \mathrm{kg} \\
\text { respiratory rate of } 12 \text { and PEEP } 5 \\
\mathrm{CmH}_{2} \mathrm{O} \text {, inspiratory time of } 33 \% \\
\text { and } 60 \% \mathrm{FiO}_{2} \\
\mathrm{CG} \text { : IMV in the } \mathrm{PC}-\mathrm{CMV} \text { mode } \\
\text { with volume of } 7 \mathrm{ml} / \mathrm{kg} \\
\text { respiratory rate of } 12 \text { and PEEP } 5 \\
\mathrm{CHH}_{2} \mathrm{O} \text {, inspiratory time of } 33 \% \\
\text { and } 60 \% \mathrm{FiO}_{2} \\
\text { Outcomes: shunt, oxygenation } \\
\text { index }\end{array}$ & $\begin{array}{l}\text { Ventilatory modes controlled } \\
\text { the volume and pressure were } \\
\text { equally effective in treating } \\
\text { hypoxemia observed in patients } \\
\text { in the postoperative immediate } \\
\text { coronary artery bypass surgery, } \\
\text { showing that the pattern of } \\
\text { administration of inspiratory } \\
\text { flow. } \\
\text { It is of little relevance for the } \\
\text { treatment of postoperative } \\
\text { hypoxemia }\end{array}$ \\
\hline $\begin{array}{c}\text { Celebi et al.[23] } \\
2008\end{array}$ & $\begin{array}{c}\text { AR, NIV, VEBH, } \\
\text { EM, IS }\end{array}$ & $\begin{array}{c}\text { NIV, VEBH, EM, } \\
\text { IS / AR, VEBH, } \\
\text { EM, IS / VEBH, } \\
\text { EM, IS }\end{array}$ & $\begin{array}{c}25 / 25 / \\
25 / 25\end{array}$ & \begin{tabular}{|c}
$52 \pm 9 / 57 \pm 8 /$ \\
$58 \pm 6 / 57 \pm 7$
\end{tabular} & $\begin{array}{l}20 / 18 / \\
21 / 22\end{array}$ & $\begin{array}{l}\text { IG: NIV through facial mask for } \\
\text { periods of one hour, starting } 6 \mathrm{~h} \\
\text { after extubation in the first } 24 \\
\text { hours, in the } \mathrm{SP} \text { mode around } \\
10 \mathrm{CmH}_{2} \mathrm{O}, \mathrm{PEEP} 5 \mathrm{cmH}_{2} \mathrm{O} \text { and } \\
\mathrm{FiO}_{2} 40 \% \text {. VEBH, EM and IS after } \\
\text { extubation } \\
\text { IG: AR in CPAP mode with peak } \\
\text { pressure } 40 \mathrm{cmH}_{2} \mathrm{O} \text { ( } 20 \mathrm{~cm} \mathrm{H}_{2} \mathrm{O} \\
\text { inspiratory pressure and } 20 \\
\mathrm{CmH}_{2} \mathrm{O} \text { PEEP) sustained for } 30 \\
\text { seconds and FiO } \text { by } 40 \% \text {. VEBH, } \\
\text { EM and IS after extubation. } \\
\text { IG: application of NIV and AR as } \\
\text { the two previously described } \\
\text { protocols. VEBH, EM and IS after } \\
\text { extubation } \\
\text { CG: maintenance of } 5 \mathrm{cmH} \mathrm{H}_{2} \mathrm{O} \\
\text { PEEP during the IMV and VEBH, } \\
\text { EM and IS after extubation } \\
\text { Outcomes: pleural effusion, } \\
\text { atelectasis, } \mathrm{VC}, \mathrm{FEV} 1\end{array}$ & $\begin{array}{l}\text { NIV associated with AR provided } \\
\text { better oxygenation both during } \\
\text { and after the mechanical } \\
\text { ventilation period. NIV either } \\
\text { alone or in combination with AR } \\
\text { provided lower atelectasis scores } \\
\text { and better early pulmonary } \\
\text { function tests compared to } \\
\text { the control group, without a } \\
\text { significant difference regarding } \\
\text { the duration of mechanical } \\
\text { ventilation, intensive care } \\
\text { unit stay, and the length of } \\
\text { hospitalization. NIV combined } \\
\text { with AR is recommended after } \\
\text { open heart surgery to prevent } \\
\text { postoperative atelectasis and } \\
\text { hypoxemia }\end{array}$ \\
\hline $\begin{array}{c}\text { Crowe and } \\
\text { Bradley }{ }^{[24]}, 1997\end{array}$ & $\begin{array}{l}\text { IS, RVE, VEBH, } \\
\text { TM, EM, TS, } \\
\text { EULL, AM, PE }\end{array}$ & $\begin{array}{c}\text { RVE, VEBH, } \\
\text { TM, EM, TS, } \\
\text { EULL, AM, PE }\end{array}$ & $90 / 95$ & $\begin{array}{l}64 \pm 8.9 / \\
64.8 \pm 8.6\end{array}$ & $74 / 79$ & $\begin{array}{l}\text { IG: PE, RVE, TM, VEBH and TS } \\
\text { once or twice a day. After } \\
\text { extubation, EULL and AM. } \\
\text { Spirometry incentive driven } \\
\text { volume used every hour by the } \\
\text { patient } \\
\text { CG: PE, RVE, TM, VEBH and } \\
\text { TS once or twice a day. After } \\
\text { extubation, EULL and AM } \\
\text { Outcomes: atelectasis, } \\
\text { pulmonary congestion, } \\
\text { pneumothorax, pleural effusion, } \\
\text { FEV1, FVC, respiratory infection, } \\
\text { SpO }_{2,} \text { days of hospitalization }\end{array}$ & $\begin{array}{l}\text { Incentive spirometry combined } \\
\text { with physical therapy is no more } \\
\text { effective than postoperative } \\
\text { physical therapy alone in } \\
\text { reducing atelectasis for } \\
\text { this population. Use of the } \\
\text { spirometer, however, was not } \\
\text { monitored, and although the } \\
\text { study mimicked practice as it } \\
\text { often occurs, the effectiveness } \\
\text { of the spirometer cannot be fully } \\
\text { evaluated }\end{array}$ \\
\hline $\begin{array}{l}\text { Dongelmans et } \\
\text { al. }{ }^{[25],}, 2009\end{array}$ & WP with SA & $\begin{array}{l}\text { WP with PC- } \\
\text { CMV and SP }\end{array}$ & $64 / 64$ & $65 \pm 9 / 67 \pm 8$ & $56 / 51$ & $\begin{array}{l}\text { IG: ventilation adapted support, } \\
\text { minute volume of } 100 \% \text { of the } \\
\text { predicted weight, } \mathrm{FiO}_{2} 50 \% \text {, } \\
\text { PEEP } 10 \mathrm{cmH}_{2} \mathrm{O} \text {, trigger the } 2 \mathrm{~L} / \mathrm{s} \\
\mathrm{CG} \text { : PC-CMV, CV 6-8 } \mathrm{ml} / \mathrm{kg} \text {, } \\
\text { respiratory rate of } 12-15 \mathrm{rpm} \text {, } \\
\mathrm{FiO}_{2} 50 \%, \mathrm{PEEP} 10 \mathrm{cmH}_{2} \mathrm{O}, 2 \\
\mathrm{~L} / \mathrm{s} \text { trigger. After spontaneous } \\
\text { ventilation with } \mathrm{SP} 10 \mathrm{cmH}_{2} \mathrm{O} \text {, } \\
\text { trigger } 2 \mathrm{~L} / \mathrm{s} \text {, expiratory } \\
\text { sensitivity } 25 \% \text { and rise time } \\
50 \mathrm{~ms} \text {. } \\
\text { Outcomes: days of ICU, length } \\
\text { of stay, } \mathrm{PaO}_{2}, \mathrm{PaCO}_{2}, \mathrm{IMV} \text { Time }\end{array}$ & $\begin{array}{c}\text { Weaning automation with SA } \\
\text { is feasible and safe in non-fast- } \\
\text { track coronary artery bypass } \\
\text { grafting patients. Time until } \\
\text { tracheal extubation with SA } \\
\text { equals time until tracheal } \\
\text { extubation with standard } \\
\text { weaning and allows for } \\
\text { frequent (automatic) switches } \\
\text { between controlled and assisted } \\
\text { ventilation }\end{array}$ \\
\hline
\end{tabular}




\begin{tabular}{|c|c|c|c|c|c|c|c|}
\hline $\begin{array}{l}\text { El-Kader }{ }^{[26]}, \\
2011\end{array}$ & $\begin{array}{c}\text { RVE, VEBH, } \\
\text { TM, IS }\end{array}$ & $\begin{array}{l}\text { RVE, VEBH, } \\
\text { TM, CPAP / } \\
\text { RVE, VEBH, } \\
\text { TM, RPPI }\end{array}$ & $\begin{array}{l}12 / 12 \\
/ 12\end{array}$ & $\begin{array}{c}48.7 \pm 6.8 \\
/ 47.4 \pm 6 / \\
49.6 \pm 7.1\end{array}$ & $\begin{array}{c}\text { Not } \\
\text { reported }\end{array}$ & $\begin{array}{l}\text { IG: } 3-5 \text { RVE followed 2-3 VEBH } \\
\text { at least } 10 \text { times in } 15 \text { minutes. } \\
\text { If necessary, positioning and } \\
\text { thoracic maneuvers. IS volume } \\
\text { for five minutes, five times a day } \\
\text { IG: } 3-5 \text { RVE followed } 2-3 \text { VEBH } \\
\text { at least } 10 \text { times in } 15 \text { minutes. } \\
\text { If necessary, positioning and } \\
\text { thoracic maneuvers. CPAP } 10 \\
\mathrm{cmH}_{2} \mathrm{O} \text { for } 15 \text { minutes daily } \\
\mathrm{CG} \text { : } 3-5 \text { RVE followed } 2-3 \text { VEBH } \\
\text { at least } 10 \text { times in } 15 \text { minutes. } \\
\text { If necessary, positioning and } \\
\text { thoracic maneuvers. RPPI with } \\
\text { inspiratory phase of } 20 \% \text {, peak } \\
\text { inspiratory pressure of } 15 \\
\mathrm{CmH}_{2} \mathrm{O} \text { for } 15 \text { minutes } \\
\text { Outcomes: } \mathrm{PaCO}_{2}, \mathrm{PaO}_{2}\end{array}$ & $\begin{array}{c}\text { Incentive spirometry in addition } \\
\text { to the usual respiratory physical } \\
\text { therapy is recommended for } \\
\text { patients in phase I of cardiac } \\
\text { rehabilitation program after } \\
\text { CABG }\end{array}$ \\
\hline $\begin{array}{c}\text { Ferreira et al[.[2]], } \\
2010\end{array}$ & IS, PEP & RVE, VEBH, EM & $8 / 8$ & $61 \pm 2 / 60 \pm 3$ & $6 / 6$ & $\begin{array}{c}\text { IG: IS volume coupled to a PEP } \\
\text { valve after extubation, with } \\
\text { increased expiratory pressure } \\
\text { progressively to } 5 \mathrm{cmH}_{2} \mathrm{O} \text { to } \\
15 \mathrm{CmH}_{2} \mathrm{O} \text { twice a day with } \\
\text { supervision and twice a day } \\
\text { without supervision, lasting } 15 \\
\text { minutes } \\
\text { CG: guidance on VEBH, EM and } \\
\text { RVE } \\
\text { Outcomes: FVC, FEV1, PEF, PI } \text { max, }_{\text {of }} \\
\text { PEmax, } 6 \mathrm{MWD} \text {, Evaluation level } \\
\text { of physical activity, evaluation of } \\
\text { quality of life }\end{array}$ & $\begin{array}{l}\text { Patients undergoing IS + PEP } \\
\text { presented less dyspnea and } \\
\text { lower sensation of effort after } \\
\text { SMWT and also better quality of } \\
\text { life } 18 \text { months after CABG }\end{array}$ \\
\hline $\begin{array}{c}\text { Franco et al. }{ }^{[28]} \\
2011\end{array}$ & $\begin{array}{c}\text { BPAP, RVE, VEBH, } \\
\text { TM, EULL, PE }\end{array}$ & $\begin{array}{l}\text { RVE, VEBH, } \\
\text { TM, EULL, PE }\end{array}$ & $13 / 13$ & Not reported & $10 / 7$ & $\begin{array}{c}\text { IG: RVE, VEBH, TM, EULL, PE for } \\
\text { two days after surgery. BPAP } \\
\text { in the spontaneous mode } \\
\text { with inspiratory pressure of } \\
8-12 \mathrm{cmH}_{2} \mathrm{O} \text { and expiratory } \\
\text { of } 6 \mathrm{cmH}_{2} \mathrm{O} \text {, twice daily for } 30 \\
\text { minutes } \\
\text { CG: RVE, VEBH, TM, EULL, PE for } \\
\text { two days after surgery } \\
\text { Outcomes: CV, MV, VC, PI max, } \\
\text { PE } \text { max }_{\text {, PEF }}\end{array}$ & $\begin{array}{l}\text { Coronary artery bypass } \\
\text { surgery leads to deterioration } \\
\text { of respiratory function } \\
\text { postoperatively, and the } \\
\text { application the BPAP may } \\
\text { be beneficial to restore lung } \\
\text { function more quickly, especially } \\
\text { vital capacity, safely, and well } \\
\text { accepted by patients due to } \\
\text { greater comfort with the feeling } \\
\text { of pain during the execution of } \\
\text { respiratory therapy }\end{array}$ \\
\hline $\begin{array}{c}\text { Garcia and } \\
\text { Costa }^{[2]]}, 2002\end{array}$ & $\begin{array}{l}\text { IMT (twice a } \\
\text { day) }\end{array}$ & $\begin{array}{l}\text { IMT (once a } \\
\text { day) / VEBH }\end{array}$ & $\begin{array}{c}20 / 20 \\
/ 20\end{array}$ & $\begin{array}{c}56 \pm 11 / \\
58 \pm 7.5 / 63 \pm 9\end{array}$ & $\begin{array}{l}13 / 16 \\
/ 11\end{array}$ & $\begin{array}{l}\text { IG: three sets of } 10 \text { repetitions, } \\
\text { twice a day. Efforts inspiratory } \\
\text { in a free load manometer for at } \\
\text { least five seconds } \\
\text { IG: three sets of } 10 \text { repetitions } \\
\text { daily. Efforts inspiratory in a free } \\
\text { load manometer for at least five } \\
\text { seconds } \\
\text { CG: conventional treatment, } \\
\text { especially VEBH } \\
\text { Outcomes: PI } I_{\text {max, }} \text { PEmax, PEF, } \\
\text { cytometry }\end{array}$ & $\begin{array}{l}\text { It was found that through a } \\
\text { specific IMT was increased } \\
\text { respiratory muscle strength both } \\
\text { the group that trained two as in } \\
\text { trained once a day, compared } \\
\text { to the control group which had } \\
\text { no change }\end{array}$ \\
\hline
\end{tabular}




\begin{tabular}{|c|c|c|c|c|c|c|c|}
\hline $\begin{array}{l}\text { Gust et al. }{ }^{[30]}, \\
1996\end{array}$ & $\mathrm{RCP}$ & CPAP / BPAP & $\begin{array}{c}25 / 25 \\
/ 25\end{array}$ & $\begin{array}{l}60.5 \pm 7.5 \\
/ 63 \pm 7 / \\
62.6 \pm 7.5\end{array}$ & $\begin{array}{c}23 / 21 \\
/ 23\end{array}$ & $\begin{array}{l}\text { IG: oxygen therapy by } \mathrm{NC} 6 \mathrm{~lm} \\
\text { and } \mathrm{RCP} \\
\text { IG: CPAP with } 7.5 \mathrm{cmH}_{2} \mathrm{O} \text { and } \\
\mathrm{FiO}_{2} \text { of } 50 \% \\
\text { CG: BPAP with } 10 \mathrm{cmH}_{2} \mathrm{O} \text { and } \\
\text { PEEP } 5 \mathrm{cmH}_{2} \mathrm{O}, \text { getting oxygen } \\
\text { to } 10 \mathrm{l} / \mathrm{m} \\
\text { Outcomes: cardiac index, } \\
\text { pulmonary blood volume index, } \\
\text { extravascular water content }\end{array}$ & $\begin{array}{l}\text { Mask CPAP and nasal BPAP } \\
\text { after extubation of the trachea } \\
\text { prevent the increase in } \\
\text { extravascular lung water during } \\
\text { weaning from mechanical } \\
\text { ventilation. } \\
\text { This effect is seen for at least } 1 \mathrm{~h} \\
\text { after the discontinuation of CPAP } \\
\text { or BPAP treatment }\end{array}$ \\
\hline 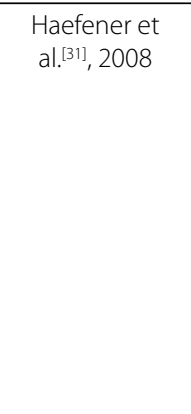 & IS, PEP & RVE, VEBH, EM & $17 / 17$ & $62 \pm 6 / 60 \pm 7$ & $14 / 14$ & $\begin{array}{l}\text { IG: IS volume associated with } \\
\text { PEP twice a day } 15-20 \text { minutes } \\
\text { with expiratory pressure } \\
\text { increased progressively } 2.5 \\
\mathrm{CmH}_{2} \mathrm{O} \text { the } 15 \mathrm{cmH}_{2} \mathrm{O} \\
\text { CG: patients were educated } \\
\text { about VEBH, EM and RVE } \\
\text { Outcomes: plethysmography, } \\
\text { 6MWD, atelectasis, pleural } \\
\text { effusion, consolidation, FVC, } \\
\text { FEV1, IMV time }\end{array}$ & $\begin{array}{l}\text { In patients undergoing CABG, } \\
\text { IS + PEP results in improved } \\
\text { pulmonary function and } \\
\text { 6-minute walk distance as well } \\
\text { as a reduction in postoperative } \\
\text { pulmonary complications }\end{array}$ \\
\hline $\begin{array}{c}\text { Hendrix et al. }{ }^{[32]}, \\
2006\end{array}$ & $\begin{array}{c}\text { WP with PRVC, } \\
\text { VS }\end{array}$ & $\begin{array}{l}\text { WP with } \\
\text { PRVC, SIMV, } \\
\text { CPAP }\end{array}$ & $10 / 10$ & $54 \pm 9 / 66 \pm 4$ & $10 / 10$ & $\begin{array}{l}\text { IG: WP with PRVC and activated } \\
\text { automatic mode function } \\
\text { triggered when the patient's } \\
\text { ventilatory cycle the mode } \\
\text { automatically changed to VSV } \\
\text { CG: WP with PRVC when the } \\
\text { patient triggered a ventilation } \\
\text { cycle, the team modified to } \\
\text { SIMV mode with frequency } \\
\text { of } 5 \text { and PS } 10 \mathrm{cmH}_{2} \mathrm{O} \text {. When } \\
\text { patients become fully alert, they } \\
\text { were changed to the mode } \\
\text { CPAP } 10 \mathrm{cmH}_{2} \mathrm{O} \\
\text { Outcomes: } \mathrm{VC}, \mathrm{FEV} 1, \mathrm{PaO}_{2} \text {, } \\
\text { PaCO}, I \mathrm{MV} \text { time }\end{array}$ & $\begin{array}{l}\text { Automode ventilator weaning } \\
\text { trended toward more } \\
\text { rapid extubation than did } \\
\text { conventional protocol driven } \\
\text { ventilation in conjunction with a } \\
\text { standardized weaning protocol. } \\
\text { Physiologic and hemodynamic } \\
\text { factors were better in patients } \\
\text { using automode ventilation } \\
\text { compared to patients using } \\
\text { conventional ventilation. } \\
\text { Automode ventilation was well } \\
\text { tolerated and did not induce } \\
\text { significant adverse effects. }\end{array}$ \\
\hline $\begin{array}{l}\text { Herdy et al. }{ }^{[33]} \\
2008\end{array}$ & $\begin{array}{l}\text { RPPI, RVE, IS, } \\
\text { AM, LA }\end{array}$ & NPI & $29 / 27$ & $61 \pm 10 \quad 58 \pm 9$ & $20 / 20$ & $\begin{array}{l}\text { IG: RPPI, RVE, IS, AM, LA five days } \\
\text { before surgery and continuing } \\
\text { after extubation to discharge. } \\
\text { Energy expenditure was } 2 \text { METS, } \\
\text { progressing up to } 4 \text { METS } \\
\text { CG: NIP } \\
\text { Outcomes: pleural effusion, } \\
\text { atelectasis, ICU days, hospital } \\
\text { days, PEF, IMV time, 6MWD }\end{array}$ & $\begin{array}{l}\text { Pre- and postoperative } \\
\text { cardiopulmonary rehabilitation } \\
\text { in patients who await CABG } \\
\text { in the hospital is superior to } \\
\text { standard care and leads to a } \\
\text { reduced rate of postoperative } \\
\text { complications and shorter } \\
\text { hospital stay }\end{array}$ \\
\hline $\begin{array}{l}\text { Hirschhorn et } \\
\text { al. }{ }^{[34]}, 2008\end{array}$ & $\begin{array}{c}\text { VEBH, PD, AM, } \\
\text { LA, PE }\end{array}$ & $\begin{array}{l}\text { PWC / IS, } \\
\text { EULL, AM }\end{array}$ & $\begin{array}{l}31 / 31 \\
/ 30\end{array}$ & $\begin{array}{c}63.6 \pm 8.5 / \\
63.2 \pm 10.8 / \\
61.8 \pm 7.2\end{array}$ & $\begin{array}{c}26 / 27 \\
/ 27\end{array}$ & $\begin{array}{l}\text { IG: five sets of } 4 \text { repetitions of IS } \\
\text { during the service and guidance } \\
\text { to perform every hour. RVE and } \\
\text { EMSI } \\
\text { IG: PWC } \\
\text { CG: PE, PD, RVE, VEBH, LA. AM } \\
\text { starting at } 10 \mathrm{~m} \text { up to } 30 \mathrm{~m} \text { in } \\
\text { the morning and night } \\
\text { Outcomes: } 6 \mathrm{MWD} \text {, VC, quality of } \\
\text { life, atelectasis, injury, failure or } \\
\text { pulmonary consolidation }\end{array}$ & $\begin{array}{l}\text { A physiotherapy-supervised, } \\
\text { moderate intensity walking } \\
\text { program in the inpatient } \\
\text { phase following CABG } \\
\text { improves walking capacity at } \\
\text { discharge from hospital. The } \\
\text { performance of respiratory } \\
\text { and musculoskeletal exercises } \\
\text { confers no additional benefit to } \\
\text { the measured outcomes }\end{array}$ \\
\hline
\end{tabular}




\begin{tabular}{|c|c|c|c|c|c|c|c|}
\hline $\begin{array}{c}\text { Jenkins et al. }{ }^{[35]}, \\
1989\end{array}$ & $\begin{array}{l}\text { RVE, VEBH, EULL, } \\
\text { AM, LA, PE, TM }\end{array}$ & $\begin{array}{l}\text { VEBH, EULL, } \\
\text { AM, LA, PE / } \\
\text { VEBH, EULL, } \\
\text { AM, LA, PE, IS }\end{array}$ & $\begin{array}{l}35 / 38 \\
/ 37\end{array}$ & $\begin{array}{c}55 \pm 8.5 / \\
56 \pm 6.9 \\
154 \pm 7.6\end{array}$ & $\begin{array}{l}35 / 38 \\
/ 37\end{array}$ & $\begin{array}{l}\text { IG: Guidance on VEBH, EULL, AM, } \\
\text { LA, PE. Three to five repetitions } \\
\text { of RVE and if necessary were } \\
\text { carried TM. At least } 10 \text { RVE every } \\
\text { hour until the fifth day after } \\
\text { surgery } \\
\text { IG: Guidance on VEBH, EULL, AM, } \\
\text { LA, PE. Three to five repetitions } \\
\text { of IS. At least } 10 \text { reps every hour } \\
\text { until the fifth day after surgery } \\
\text { CG: Guidance on VEBH, EULL, } \\
\text { AM, LA, PE } \\
\text { Outcomes: FEV1, PEF, FVC, } \\
\text { consolidation, PaCO, PaO, } \\
\text { pain }\end{array}$ & $\begin{array}{l}\text { It is concluded that the } \\
\text { addition of breathing exercises } \\
\text { or incentive spirometry to a } \\
\text { regimen of early mobilization } \\
\text { and huffing and coughing } \\
\text { confers no extra benefit after } \\
\text { uncomplicated coronary artery } \\
\text { bypass grafting }\end{array}$ \\
\hline $\begin{array}{l}\text { Johnson et } \\
\text { al. }{ }^{[36]}, 1995\end{array}$ & RVE, EM & $\begin{array}{l}\text { RVE, SMI, } \\
\text { EM (group } \\
\text { with minimal } \\
\text { atelectasis) } \\
\text { / RVE, SMI, } \\
\text { EM (group } \\
\text { marked } \\
\text { atelectasis) / } \\
\text { RVE, SMI, TM, } \\
\text { EM }\end{array}$ & \begin{tabular}{|c|}
$48 / 49 /$ \\
$64 / 63$
\end{tabular} & $\begin{array}{c}60 \pm 10 / \\
64 \pm 11 / 66 \pm 8 \\
/ 64 \pm 11\end{array}$ & $\begin{array}{c}39 / 40 / \\
52 / 53\end{array}$ & $\begin{array}{l}\text { IG: EM and five repetitions of } \\
\text { RVE every hour } \\
\text { IG: group with minimal } \\
\text { atelectasis. EM and five } \\
\text { repetitions of SMI starting from } \\
\text { the residual functional capacity } \\
\text { to total lung capacity } \\
\text { IG: group marked atelectasis. } \\
\text { EM and five repetitions of } \\
\text { SMI starting from the residual } \\
\text { functional capacity to total lung } \\
\text { capacity } \\
\text { CG: During the operation of SMI, } \\
\text { application TM with frequency } \\
\text { of 1-2 per second and EM. Three } \\
\text { daily sessions. } \\
\text { Outcomes: atelectasis, VC, FVC, } \\
\text { FEV1, days of hospitalization, } \\
\text { PI max, PEmax, pain }\end{array}$ & $\begin{array}{l}\text { We concluded that } \\
\text { postoperative respiratory } \\
\text { dysfunction is common but } \\
\text { does not commonly cause } \\
\text { significant morbidity or prolong } \\
\text { hospital stay. Adding SMl to } \\
\text { patients with minimal atelectasis } \\
\text { at extubation does not improve } \\
\text { clinical outcomes. Similarly, } \\
\text { adding TM to patients with } \\
\text { marked atelectasis does not } \\
\text { improve outcomes over those } \\
\text { obtained with SMl and early } \\
\text { ambulation }\end{array}$ \\
\hline $\begin{array}{c}\text { Marvel et al. }{ }^{[37]}, \\
1986\end{array}$ & $\begin{array}{l}\text { WP with } \\
\text { ambient } \\
\text { pressure }\end{array}$ & $\begin{array}{l}\text { WP with PEEP } \\
\text { of } 5 \mathrm{cmH}_{2} \mathrm{O} \text {, } \\
\mathrm{CPAP} \text { of } 5 \\
\mathrm{CmH}_{2} \mathrm{O} / \text { WP } \\
\text { with PEEP } 10 \\
\mathrm{CmH}_{2} \mathrm{O}\end{array}$ & $\begin{array}{l}17 / 15 \\
/ 12\end{array}$ & $\begin{array}{c}62.7 \pm 1.7 / \\
60.9 \pm 2.9 / \\
55.8 \pm 2.7\end{array}$ & $\begin{array}{c}\text { Not } \\
\text { reported }\end{array}$ & $\begin{array}{l}\text { IG:WP pressure environment } \\
\text { IG: WP with } 5 \mathrm{cmH}_{2} \mathrm{O} \text { and CPAP } \\
5 \mathrm{cmH}_{2} \mathrm{O} \text { for an hour and a half } \\
\text { before extubation } \\
\mathrm{CG}: \text { WP with } 10 \mathrm{cmH}_{2} \mathrm{O} \text { and } \\
\mathrm{CPAP} 5 \mathrm{cmH}_{2} \mathrm{O} \text { for half an hour } \\
\text { before extubation } \\
\text { Outcomes: atelectasis, days of } \\
\text { hospitalization, } \mathrm{PaO}_{2}\end{array}$ & $\begin{array}{l}\text { We conclude that routine } \\
\text { PEEP improves pulmonary } \\
\text { oxygen transfer but, once } \\
\text { discontinued, PEEP offers no } \\
\text { sustained beneficial effect upon } \\
\text { impaired oxygen transfer or } \\
\text { roentgenographic evidence of } \\
\text { atelectasis following CABG }\end{array}$ \\
\hline $\begin{array}{l}\text { Matheus et } \\
\text { al. }{ }^{[38]}, 2012\end{array}$ & $\begin{array}{l}\text { IMT, RVE, IS, } \\
\text { AM, PE }\end{array}$ & RVE, IS, AM, PE & $23 / 24$ & $\begin{array}{c}61.8 \pm 13.5 / \\
63.3 \pm 10.2\end{array}$ & $18 / 16$ & $\begin{array}{l}\text { IG: RVE, IS, AM, PE and IMT twice } \\
\text { a day with three sets of } 10 \\
\text { repetitions with } 40 \% \text { of MIP } \\
\text { CG: RVE, IS, AM, PE } \\
\text { Outcomes: PImax, PEmax, CV, VC, } \\
\text { PEF, pleural effusion, atelectasis, } \\
\text { ICU days, hospital days, IMV time }\end{array}$ & $\begin{array}{l}\text { Patients undergoing cardiac } \\
\text { surgery } \\
\text { suffer reduction of VC and } \\
\text { respiratory muscle strength after } \\
\text { the surgery. The muscle training } \\
\text { performed was effective in } \\
\text { recovering the CV and VC in PO3, } \\
\text { the trained group }\end{array}$ \\
\hline $\begin{array}{c}\text { Matte et al. }{ }^{[39]}, \\
2000\end{array}$ & $\begin{array}{l}\text { VEBH, EM, IS, } \\
\text { NBL }\end{array}$ & $\begin{array}{l}\text { RVE, EM, IS, } \\
\text { NBL, CPAP / } \\
\text { VEBH, EM, IS, } \\
\text { NBL, BPAP }\end{array}$ & $\begin{array}{c}30 / 33 \\
/ 33\end{array}$ & $\begin{array}{c}63 \pm 8 / 65 \pm 8 / \\
64 \pm 9\end{array}$ & $\begin{array}{c}25 / 30 \\
/ 30\end{array}$ & $\begin{array}{l}\text { IG: Routine physiotherapy } \\
\text { (VEBH, NBL, EM and IS) } \\
\text { IG: Routine physiotherapy, CPAP } \\
5 \mathrm{CmH}_{2} \mathrm{O} \\
\text { CG: Routine physiotherapy, BPAP } \\
\text { with the inspiratory pressure } 12 \\
\mathrm{CmH}_{2} \mathrm{O} \text { and expiratory pressure } \\
5 \mathrm{cmH}_{2} \mathrm{O} \\
\text { Outcomes: } \mathrm{VC} \text {, FEV1, } \mathrm{PaO}_{2} \\
\mathrm{PaCO}_{2} \text {, atelectasis, days of ICU }\end{array}$ & $\begin{array}{l}\text { We conclude that preventive } \\
\text { use of NIV can be considered as } \\
\text { an effective means to decrease } \\
\text { the negative effect of coronary } \\
\text { surgery on pulmonary function }\end{array}$ \\
\hline
\end{tabular}




\begin{tabular}{|c|c|c|c|c|c|c|c|}
\hline $\begin{array}{l}\text { Mendes et } \\
\text { al. }{ }^{[40]}, 2010\end{array}$ & $\begin{array}{l}\text { RVE, VEBH, PD, } \\
\text { TM, EM, PE, EE, } \\
\text { EULL, AM, LA }\end{array}$ & $\begin{array}{c}\text { RVE, VEBH, PD, } \\
\text { TM, EM, PE }\end{array}$ & $24 / 23$ & $60 \pm 8 / 58 \pm 9$ & $16 / 20$ & $\begin{array}{l}\text { IG: Four sets of } 10 \text { repetitions } \\
\text { of RVE and VEBH once daily. If } \\
\text { necessary, PD and TM } \\
\text { CG: Four sets of } 10 \text { repetitions } \\
\text { of RVE and VEBH once daily. If } \\
\text { necessary, PD and TM. EE with } \\
\text { five sets of } 10 \text { repetitions, EULL } \\
\text { with two sets of } 15 \text { reps, } 10 \\
\text { minutes AM, LA-four steps } \\
\text { Outcomes: ICU days, hospital } \\
\text { days, IMV time, heart rate and } \\
\text { RR interval }\end{array}$ & $\begin{array}{l}\text { Short-term supervised } \\
\text { physiotherapy exercise protocol } \\
\text { during inpatient cardiac } \\
\text { rehabilitation improves cardiac } \\
\text { autonomous regulation at } \\
\text { the time of discharge. Thus, } \\
\text { exercise-based inpatient cardiac } \\
\text { rehabilitation might be an } \\
\text { effective non-pharmacological } \\
\text { tool to improve autonomic } \\
\text { cardiac tone in patient's post- } \\
\text { CABG }\end{array}$ \\
\hline $\begin{array}{l}\text { Michalopoulos } \\
\text { et al. }{ }^{[41]}, 1998\end{array}$ & WP with ZEEP & $\begin{array}{l}\text { WP with PEEP } \\
\text { of } 5 \mathrm{cmH}_{2} \mathrm{O} / \\
\text { WP with PEEP } \\
\text { of } 10 \mathrm{cmH}_{2} \mathrm{O}\end{array}$ & $\begin{array}{c}22 / 24 \\
/ 21\end{array}$ & $\begin{array}{c}61.1 \pm 6.1 / \\
60.9 \pm 6.2 / \\
61.9 \pm 6.6\end{array}$ & $\begin{array}{c}18 / 20 \\
/ 16\end{array}$ & $\begin{array}{c}\text { IG: ZEEP during IMV } \\
\text { postoperatively until extubation } \\
\text { IG: PEEP } 5 \mathrm{cmH}_{2} \mathrm{O} \text { during IMV } \\
\text { postoperatively until extubation } \\
\text { CG: PEEP } 10 \mathrm{cmH}_{2} \mathrm{O} \text { during IMV } \\
\text { postoperatively until extubation } \\
\text { Outcomes: atelectasis, IMV time, } \\
\text { oxygenation index, cardiac } \\
\text { index }\end{array}$ & $\begin{array}{l}\text { We concluded that low levels } \\
\text { of PEEP have no advantage } \\
\text { over zero PEEP in improving } \\
\text { gas exchange in the early } \\
\text { postoperative course of patients } \\
\text { following open heart surgery }\end{array}$ \\
\hline $\begin{array}{l}\text { Muller et al. }{ }^{[42]}, \\
2006\end{array}$ & CPAP & RPPI & $20 / 20$ & $\begin{array}{l}61 \pm 5.8 / \\
62.1 \pm 7.3\end{array}$ & $16 / 17$ & $\begin{array}{l}\text { IG: } \mathrm{CPAP} \text { to } 5 \mathrm{cmH}_{2} \mathrm{O} \text { and } 3 \mathrm{l} / \mathrm{m} \\
\text { oxygen within } 3 \text { hours for } 15 \\
\text { minutes every hour, on the } 24^{\text {th }} \\
\text { and } 48^{\text {th }} \text { postoperative for } 30 \\
\text { minutes in two } 15 \text {-minute sets } \\
\mathrm{CG} \text { : } \mathrm{RPPI} 20 \mathrm{cmH}_{2} \mathrm{O} \text { the } 30 \\
\mathrm{CmH}_{2} \mathrm{O} \text { with serum as diluent } \\
\text { in the micronebulizer. Within } \\
3 \text { hours for } 15 \text { minutes every } \\
\text { hour, on the } 24^{\text {th }} \text { and } 48^{\text {th }} \\
\text { postoperative for } 30 \text { minutes in } \\
\text { two } 15 \text {-minute sets } \\
\text { Outcomes: } \mathrm{PaO}_{2}, \text { PaCO } \\
\text { dyspnea, ventilometry }\end{array}$ & $\begin{array}{l}\text { Both devices were shown to } \\
\text { be able to keep } \mathrm{pO}_{2}, \mathrm{pCO}_{2} \text {, and } \\
\mathrm{SPO}_{2} \text { values within normal limits. } \\
\text { However, when the objective } \\
\text { was pulmonary reexpansion } \\
\text { with less imposed workload, the } \\
\text { Müller resuscitator was more } \\
\text { effective because of its prompter } \\
\text { action and consequently lower } \\
\text { levels of dyspnea, respiratory } \\
\text { rate (RR) and use of accessory } \\
\text { muscle were observed }\end{array}$ \\
\hline $\begin{array}{l}\text { Oikkonen et } \\
\text { al. }{ }^{[43]}, 1991\end{array}$ & IS, PE & RPPI, PE & $26 / 26$ & $55 \pm 1 / 55 \pm 1$ & $22 / 22$ & $\begin{array}{c}\text { IG: PE with guidance on RVE, } \\
\text { VEBH. IS volume with } 3 \text { seconds } \\
\text { support at least } 5 \text { times per } \\
\text { training } \\
\text { CG: PE with guidance on RVE, } \\
\text { VEBH. RPPI with a peak pressure } \\
\text { of } 10 \text { to } 15 \mathrm{cmH}_{2} \mathrm{O} \text { pressure for } \\
\text { not less than } 4 \text { daily sessions } \\
\text { Outcomes: atelectasis, } \\
\text { congestion, pleural effusion, } \\
\text { diaphragm elevation, } \mathrm{VC}, \mathrm{PEF}, \\
\mathrm{PaO}_{2}, \mathrm{PaCO}_{2}\end{array}$ & $\begin{array}{c}\text { Based on the three variables } \\
\text { studied, we consider both } \\
\text { devices equal in efficiency after } \\
\text { coronary surgery }\end{array}$ \\
\hline $\begin{array}{l}\text { Renault et al[.[4]] } \\
2009\end{array}$ & $\begin{array}{c}\text { RVE, VEBH, EM, } \\
\text { NIV }\end{array}$ & $\begin{array}{l}\text { VEBH, EM, IS, } \\
\text { NIV }\end{array}$ & $18 / 18$ & $\begin{array}{c}54.8 \pm 7.4 / \\
58.7 \pm 9.2\end{array}$ & $13 / 16$ & $\begin{array}{c}\text { IG: EM, VEBH, NIV with two } \\
\text { pressure levels for } 30 \text { minutes } \\
\text { twice a day in the ICU and once } \\
\text { in the inpatient unit. RVE three } \\
\text { sets of ten repetitions } \\
\text { CG: EM, VEBH, NIV with two } \\
\text { pressure levels for } 30 \text { minutes } \\
\text { twice a day in the ICU and once in } \\
\text { the inpatient unit. IS three sets of } \\
\text { ten repetitions with the position } \\
\text { of the adjustment ring 0-2, } \\
\text { prioritizing slow flows } \\
\text { Outcomes: PI max, PEmax, FVC, } \\
\text { FEV1, IMV time }\end{array}$ & $\begin{array}{c}\text { No significant differences } \\
\text { were observed in maximal } \\
\text { respiratory pressures, spirometric } \\
\text { variables and oxygen saturation } \\
\text { in patients undergoing } \\
\text { deep breathing exercises } \\
\text { and incentive spirometry in } \\
\text { postoperative coronary artery } \\
\text { bypass surgery }\end{array}$ \\
\hline
\end{tabular}




\begin{tabular}{|c|c|c|c|c|c|c|c|}
\hline $\begin{array}{l}\text { Richter Larsen } \\
\text { et al. }{ }^{[45]}, 1995\end{array}$ & $\begin{array}{c}\text { RVE, VEBH, EM, } \\
\text { AM, PE, PEP }\end{array}$ & $\begin{array}{l}\text { RVE, VEBH, } \\
\text { EM, AM, PE, } \\
\text { IR, PEP / RVE, } \\
\text { VEBH, EM, } \\
\text { AM, PE }\end{array}$ & $\begin{array}{c}\text { Not } \\
\text { reported }\end{array}$ & Not reported & $\begin{array}{c}\text { Not } \\
\text { reported }\end{array}$ & $\begin{array}{l}\text { IG: Twice a day RVE, VEBH and } \\
\text { EM. PEP with } 10-15 \mathrm{cmH}_{2} \mathrm{O} \\
\text { IG: Twice a day } \mathrm{RVE}, \mathrm{VEBH} \text { and } \\
\text { EM. IR around } 20 \mathrm{CmH}_{2} \mathrm{O} \text { and } \\
\text { PEP of } 10-15 \mathrm{CmH}_{2} \mathrm{O} \\
\text { CG: twice a day RVE, VEBH and } \\
\text { EM } \\
\text { Outcomes: Atelectasis, FVC, } \\
\qquad \mathrm{PaO}_{2}\end{array}$ & $\begin{array}{l}\text { We did not find any significant } \\
\text { difference among the three } \\
\text { groups; however, a tendency to } \\
\text { decreased risk of having post } \\
\text { operative complications was } \\
\text { observed in the groups having } \\
\text { positive expiratory pressure and } \\
\text { inspiratory resistance-positive } \\
\text { expiratory pressure }\end{array}$ \\
\hline $\begin{array}{l}\text { Romanini et } \\
\text { al. }{ }^{[46]}, 2007\end{array}$ & RPPI & IS & $20 / 20$ & $\begin{array}{c}56.4 \pm 8.8 / \\
57.1 \pm 9.8\end{array}$ & $12 / 16$ & $\begin{array}{l}\text { IG: RPPI for ten minutes, five } \\
\text { minutes interval and again } \\
\text { applied for ten minutes } \\
\text { CG: IS volume for ten minutes, } \\
\text { five minutes interval and again } \\
\text { applied for ten minutes } \\
\text { Outcomes: FEV1, Tiffenau index, } \\
\text { PI } \text { Imax }_{\text {, PEmax }} \text { ventilometry }\end{array}$ & $\begin{array}{l}\text { In order to reverse hypoxemia } \\
\text { earlier, the RPPI was more } \\
\text { efficient compared to IS; } \\
\text { however, to improve the } \\
\text { strength of respiratory muscles, } \\
\text { it was more effective }\end{array}$ \\
\hline $\begin{array}{c}\text { Savci et al.[47], } \\
2011\end{array}$ & $\begin{array}{c}\text { IMT, RVE, VEBH, } \\
\text { EM, EULL, AM, } \\
\text { LA }\end{array}$ & $\begin{array}{c}\text { RVE, VEBH, } \\
\text { EM, EULL, } \\
\text { AM, LA }\end{array}$ & $22 / 21$ & $\begin{array}{c}62.8 \pm 8.6 / \\
57.4 \pm 1.4\end{array}$ & $19 / 19$ & $\begin{array}{c}\text { IG: IMT twice a day for ten } \\
\text { days (five before and five } \\
\text { postoperatively), EM, EULL, RVE, } \\
\text { VEBH, AM, LA } \\
\text { CG: EM, EULL, RVE, VEBH, AM, LA } \\
\text { Outcomes: atelectasis, pleural } \\
\text { effusion, consolidation, FVC, } \\
\text { FEV1, Tifennau index, PI } \text { max, }_{\text {max }} \\
\text { PEEmax, 6MWD, quality of life }\end{array}$ & $\begin{array}{l}\text { IMT results in faster recovery } \\
\text { of inspiratory muscle strength, } \\
\text { functional capacity, intensive } \\
\text { care unit stay, quality of life and } \\
\text { psychosocial status after CABG }\end{array}$ \\
\hline $\begin{array}{l}\text { Savci et al.[48], } \\
2006\end{array}$ & $\begin{array}{l}\text { RVE, VEBH, EM, } \\
\text { EULL, AM, CAR }\end{array}$ & $\begin{array}{c}\text { RVE, VEBH, } \\
\text { EM, EULL, } \\
\text { AM, IS }\end{array}$ & $30 / 30$ & $\begin{array}{c}55.2 \pm 8.5 / \\
57.2 \pm 8.9\end{array}$ & $30 / 30$ & $\begin{array}{l}\text { IG: RVE, VEBH, EM, EULL. AM } \\
30 \text { and } 80 \mathrm{~m} \text { in the morning } \\
\text { and afternoon on the first } \\
\text { postoperative day. On the } \\
\text { second day, AM for five minutes. } \\
\text { On the third day, the walk } \\
\text { was free in the hallway. CAR } \\
\text { consisted of 1-2 controlled } \\
\text { breaths, followed } 3 \text { RVE } \\
\text { inspiratory pause of } 3 \text { seconds, } \\
\text { controlled breaths 1-2 VEBH } \\
\text { CG: RVE, VEBH, EM, EULL. AM } \\
30 \text { and } 80 \text { m in the morning } \\
\text { and afternoon on the first } \\
\text { postoperative day. On the } \\
\text { second day, AM for five } \\
\text { minutes. On the third day, the } \\
\text { walk was free in the hallway. } \\
\text { IS was applied followed by } 3 \\
\text { repetitions inspiratory pause of } \\
3 \text { seconds. VEBH 1-2 controlled } \\
\text { breaths. By the second day after } \\
\text { surgery, two daily sessions and } \\
\text { after, once a day, } 15 \text { minutes } \\
\text { session } \\
\text { Outcomes: VC, FVC, FEV1, PEF, } \\
6 \text { MWD, atelectasis, congestion, } \\
\text { infiltration, pneumothorax, } \\
\text { pleural effusion, pulmonary } \\
\text { edema, pain }\end{array}$ & $\begin{array}{c}\text { Both treatments improved } \\
\text { arterial oxygenation from the } \\
\text { first day of the postoperative } \\
\text { period. } \\
\text { After a 5-day treatment, } \\
\text { functional capacity was well } \\
\text { preserved with the usage of } \\
\text { CAR or IS } \\
\text { Both physiotherapy methods } \\
\text { had similar effects on the rate of } \\
\text { atelectasis, pulmonary function, } \\
\text { and pain perception }\end{array}$ \\
\hline
\end{tabular}




\begin{tabular}{|c|c|c|c|c|c|c|c|}
\hline $\begin{array}{l}\text { Stein et al.[49] } \\
2009\end{array}$ & $\begin{array}{c}\text { Medical } \\
\text { consultation } \\
\text { and nursing, } \\
\text { RVE, VEBH, EE, } \\
\text { EULL, AM, LA, } \\
\text { PE, PEP }\end{array}$ & $\begin{array}{l}\text { PE, medical } \\
\text { consultation } \\
\text { and nursing }\end{array}$ & $10 / 10$ & $64 \pm 7 / 63 \pm 6$ & $6 / 5$ & $\begin{array}{c}\text { IG: Medical consultation and } \\
\text { nursing, PE, VEBH, RVE, EE, EULL, } \\
\text { AM, LA, PEP with progressive } \\
\text { pressure } 3-8 \mathrm{cmH}_{2} \mathrm{O} \text { for } 3-12 \\
\text { minutes } \\
\text { CG: PE, medical visits and } \\
\text { nursing } \\
\text { Outcomes: FVC, FEV1, PI } \\
\text { PEmax, } \\
\text { PMWT, dyspnea, IMV time }\end{array}$ & $\begin{array}{l}\text { A 6-day rehabilitation program } \\
\text { attenuated the postoperative } \\
\text { reduction in respiratory muscle } \\
\text { strength and also improved the } \\
\text { recovery of functional capacity } \\
\text { after CABG. The correlation } \\
\text { between } \mathrm{PI} \text { max and } \mathrm{VO}_{2} \text { peak } \\
\text { during the late postoperative } \\
\text { period suggests that inspiratory } \\
\text { muscle strength is an important } \\
\text { determinant of functional } \\
\text { capacity after CABG }\end{array}$ \\
\hline $\begin{array}{c}\text { Stiller et al. }{ }^{[50]}, \\
1994\end{array}$ & $\begin{array}{l}\text { PE and RVE, } \\
\text { VEBH, TM, PD } \\
\text { (twice a day) }\end{array}$ & $\begin{array}{c}\text { PE and RVE, } \\
\text { VEBH, TM, PD } \\
\text { (four times a } \\
\text { day) / NPI }\end{array}$ & $\begin{array}{l}40 / 40 \\
/ 40\end{array}$ & $\begin{array}{c}61 \pm 9 / 63 \pm 8 / \\
62 \pm 11\end{array}$ & $\begin{array}{c}33 / 32 \\
/ 33\end{array}$ & $\begin{array}{l}\text { IG: PE, RVE, VEBH (2x / day } \\
\text { for the first two days of PO } \\
\text { and e } 1 \times \text { / day } 3 \text { and } 4 \text { PO. } \\
\text { 3-5 EVR followed 2-3 HB (also } \\
\text { independently every hour). If } \\
\text { necessary TM and PD } \\
\text { IG: PE, RVE, VEBH (4x / day } \\
\text { for the first } 2 \text { days of PO and } \\
\text { 2x / day } 3 \text { and } 4 \text { PO. 3-5 RVE } \\
\text { followed 2-3 VEBH (also } \\
\text { independently every hour) if } \\
\text { necessary TM and PD } \\
\text { CG: No physical therapy } \\
\text { intervention in the pre- or } \\
\text { postoperative period } \\
\text { Outcomes: FVC, days of } \\
\text { hospitalization, IMV time, PaOz, } \\
\text { PaCO }{ }_{2} \text {, oxygenation index }\end{array}$ & $\begin{array}{l}\text { The necessity for prophylactic } \\
\text { chest physiotherapy after } \\
\text { routine coronary artery surgery } \\
\text { should be reviewed }\end{array}$ \\
\hline $\begin{array}{c}\text { Sulzer et al. }{ }^{[51]}, \\
2001\end{array}$ & WP with SA & WP with SIMV & $16 / 20$ & $\begin{array}{c}59.2 \pm 8.7 / \\
59.7 \pm 8.1\end{array}$ & $12 / 14$ & $\begin{array}{l}\text { IG: WP with } \mathrm{SA} 100 \% \text { of minute } \\
\text { ventilation, } 100 \% \mathrm{FiO}_{2}, 4 \mathrm{cmH}_{2} \mathrm{O} \\
\text { PEEP, peak pressure } 25 \mathrm{~cm} \mathrm{H}_{2} \mathrm{O} \\
\text { and sensitivity } 2 \mathrm{I} / \mathrm{min} \\
\mathrm{CG} \text { :WP with } \mathrm{SIMV} \text {, tidal volume } \\
\text { of } 7 \mathrm{ml} / \mathrm{kg} \text {, decelerating flow, } \\
\text { respiratory rate of } 12,100 \% \\
\mathrm{FiO}_{2}, \mathrm{PEEP} 4 \mathrm{cmH}_{2} \mathrm{O} \text {, sensitivity } \\
21 / \text { min } \\
\text { Outcomes: days of ICU, IMV } \\
\text { time, } \mathrm{PaO}_{2} \text {, oxygenation index }\end{array}$ & $\begin{array}{c}\text { A respiratory weaning protocol } \\
\text { based on SA is practicable; } \\
\text { it may accelerate tracheal } \\
\text { extubation and simplify } \\
\text { ventilatory management in } \\
\text { fast-track patients after cardiac } \\
\text { surgery. } \\
\text { The evaluation of potential } \\
\text { advantages of the use of such } \\
\text { technology on patient outcome } \\
\text { and resource utilization deserves } \\
\text { further studies }\end{array}$ \\
\hline $\begin{array}{c}\text { Thomas et al. } \\
1992\end{array}$ & Nasal CPAP & $\begin{array}{l}\text { Oxygen by } \\
\text { mask }\end{array}$ & $14 / 14$ & $59 \pm 4 / 55 \pm 10$ & $14 / 14$ & $\begin{array}{c}\text { IG: on the first day after surgery, } \\
60 \text { minutes of nasal CPAP with } 5 \\
\mathrm{CmH}_{2} \mathrm{O} \text { pressure } \\
\text { CG: use of facial mask for } \\
\text { oxygen therapy } \\
\text { Outcomes: pain, pulmonary } \\
\text { shunt, cardiac index }\end{array}$ & $\begin{array}{l}\text { We conclude that the use of } \\
\text { nasal CPAP is a simple, tolerable } \\
\text { and effective method of treating } \\
\text { hypoxemia in adult patients after } \\
\text { coronary artery bypass surgery } \\
\text { and warrants further study }\end{array}$ \\
\hline
\end{tabular}




\begin{tabular}{|c|c|c|c|c|c|c|c|}
\hline $\begin{array}{l}\text { Westerdahl et } \\
\text { al.[53], } 2001\end{array}$ & $\begin{array}{l}\text { RVE, VEBH, EM, } \\
\text { EULL, AM, blow } \\
\text { bottle }\end{array}$ & $\begin{array}{c}\text { RVE, VEBH, } \\
\text { EM, EULL, AM, } \\
\text { RI and PEP } \\
\text { / RVE, VEBH, } \\
\text { EM, EULL, AM }\end{array}$ & $\begin{array}{c}36 / 30 \\
/ 32\end{array}$ & $\begin{array}{c}66 \pm 9.4 / \\
65.9 \pm 8.8 / \\
63.5 \pm 9.2\end{array}$ & $\begin{array}{c}36 / 30 \\
/ 32\end{array}$ & $\begin{array}{c}\text { IG: EM, EULL, VEBH, AM. RVE in } \\
\text { blow bottle, with } 10 \mathrm{~cm} \text { of water } \\
\text { and plastic tube with } 40 \mathrm{~cm} \text { long } \\
\text { and } 1 \mathrm{~cm} \text { in diameter, generating } \\
\text { an expiratory resistance of } 10 \\
( \pm 1) \mathrm{cmH}_{2} \mathrm{O} \text {. } 30 \text { replicates were } \\
\text { performed for RVE every hour } \\
\text { during the day } \\
\text { IG: EM, EULL, VEBH, AM. RVE } \\
\text { through a face mask connected to } \\
\text { a T tube with PEP } 10 \mathrm{~cm} \mathrm{H}_{2} \mathrm{O} \text { and } \\
\mathrm{RI}-5 \mathrm{~cm} \mathrm{H}_{2} \mathrm{O} \text {. Thirty replicates were } \\
\text { performed for RVE every hour } \\
\text { during the day } \\
\text { CG: EM, EULL, VEBH, AM and } \\
\text { RVE without any device. Thirty } \\
\text { replicates were performed for RVE } \\
\text { every hour during the day } \\
\text { Outcomes: } \mathrm{VC} \text {, inspiratory } \\
\text { capacity, FEV1, RV, TLC, diffusing } \\
\text { capacity, pain, atelectasis, pleural } \\
\text { effusion }\end{array}$ & $\begin{array}{l}\text { No major differences among } \\
\text { the treatment groups were } \\
\text { found, but the impairment in } \\
\text { pulmonary function tended to } \\
\text { be less marked using the blow } \\
\text { bottle technique. The blow } \\
\text { bottle group had signicantly less } \\
\text { reduction in total lung capacity } \\
\text { compared to the deep breathing } \\
\text { group, while the IR-PEP group } \\
\text { did not signi. cantly differ from } \\
\text { the other two groups. }\end{array}$ \\
\hline $\begin{array}{l}\text { Westerdahl et } \\
\text { al. }{ }^{[54]}, 2005\end{array}$ & $\begin{array}{c}\text { VEBH, EM, AM, } \\
P E\end{array}$ & $\begin{array}{l}\text { RVE, VEBH, } \\
\text { EM, AM, PE, } \\
\text { blow bottle }\end{array}$ & $48 / 42$ & $66 \pm 9 / 65 \pm 9$ & $36 / 31$ & $\begin{array}{l}\text { IG: care given once or twice daily } \\
\text { for the first four days. EM, VEBH, PE } \\
\text { and AM } \\
\text { CG: PE, EM, VEBH, AM. Three sets of } \\
10 \text { repetitions of RVE were carried } \\
\text { through every hour during the } \\
\text { day, in the first four days. RVE in the } \\
\text { blow bottle, with } 10 \mathrm{~cm} \text { of water } \\
\text { and plastic tube with } 50 \mathrm{~cm} \text { long } \\
\text { and } 1 \mathrm{~cm} \text { in diameter, generating } \\
\text { an expiratory resistance } 10 \mathrm{cmH}_{2} \mathrm{O} \\
\text { Outcomes: } \mathrm{VC}, \mathrm{FVC}, \text { FEV1, } \\
\text { inspiratory capacity, residual } \\
\text { functional capacity, } T \mathrm{CL}, \text { atelectasis, } \\
\text { PaO } \mathrm{PaCO}_{2} \text {, Pain, IMV time }\end{array}$ & $\begin{array}{l}\text { Patients performing deep- } \\
\text { breathing exercises after } \\
\text { CABG surgery had significantly } \\
\text { smaller atelectatic areas and } \\
\text { better pulmonary function on } \\
\text { the fourth postoperative day } \\
\text { compared to a control group } \\
\text { performing no exercises }\end{array}$ \\
\hline 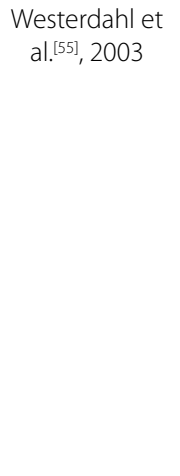 & RVE & $\begin{array}{c}\text { RVE, blow } \\
\text { bottle/RVE, RI } \\
\text { and PEP }\end{array}$ & $\begin{array}{c}21 / 20 \\
/ 20\end{array}$ & $\begin{array}{c}66 \pm 9 / 64 \pm 8 / \\
64 \pm 10\end{array}$ & $\begin{array}{l}18 / 16 \\
/ 15\end{array}$ & $\begin{array}{l}\text { IG: three sets of } 10 \text { repetitions of } \\
\text { RVE without any device } \\
\text { IG: three sets of } 10 \text { repetitions of } \\
\text { RVE in the blow bottle, with } 10 \\
\mathrm{~cm} \text { of water and plastic tube with } \\
50 \mathrm{~cm} \text { long and } 1 \mathrm{~cm} \text { in diameter, } \\
\text { generating an } \mathrm{RE} 10 \mathrm{cmH}_{2} \mathrm{O} \\
\text { CG: three sets of } 10 \text { repetitions } \\
\text { of RVE through a face mask } \\
\mathrm{connected} \mathrm{to} \mathrm{a} \mathrm{T} \mathrm{tube} \mathrm{with} \mathrm{PEP} 15 \\
\mathrm{CmH}_{2} \mathrm{O} \text { and } \mathrm{R} \text { - }-5 \mathrm{cmH}_{2} \mathrm{O} \\
\text { Outcomes: atelectasis, } \mathrm{PaO}_{2} \text {, } \\
\text { PaCO}, I \mathrm{MV} \text { time }\end{array}$ & $\begin{array}{c}\text { A significant decrease of } \\
\text { atelectatic area, } \\
\text { increase in aerated lung area } \\
\text { and a small increase in } \mathrm{PaO}_{2} \\
\text { were found after performance of } \\
30 \text { deep breaths. } \\
\text { No difference among the three } \\
\text { breathing techniques was found }\end{array}$ \\
\hline
\end{tabular}

AR - alveolar recruitment; AM - ambulation; BPAP - bilevel positive pressure airway; CAR - active cycle of breathing; CG - control group; CPAP - continuous positive airway pressure; Cstat - static compliance; CV - current volume; EE - ends exercises; EM - early mobilization; EULL - exercise upper and lower limbs; FEV1 - forced expiratory volume in one second $\mathrm{FiO}_{2}$ - inspiratory oxygen fraction; FVC - forced vital capacity; ICU - intensive care unit; IG - intervention group; IMV - invasive mechanical ventilation; IMT - inspiratory muscle training; IS - incentive spirometry; LA -ladder; MH - manual hyperinflation; MV minute volume; NBL - nebulization; NC - nasal catheter; NIV - non-invasive ventilation; NPI - none physiotherapy intervention; PaCO2- partial pressure of carbon dioxide; $\mathrm{PaO}_{2}$ - partial pressure of oxygen; PC-CMV - Pressure-control continuous mandatory ventilation; PD - postural drainage; PE - preoperative education; PEmax - maximal expiratory pressure; PEEP - positive end-expiratory pressure; PEF - peak expiratory flow; PEP - positive expiratory pressure; PImax - maximal inspiratory pressure; PRVC - pressure regulated volume control; PWC - progressive walking circuit; RI -inspiratory resistance; RCP - routine chest physiotherapy; RE - expiratory resistance; RPPI - intermittent positive pressure breathing; RV - residual volume; RVE - re-expansive ventilatory exercises; SA - support adapted; SIMV - synchronized intermittent mandatory ventilation; SMI - sustained maximal inspirations; 6MWD - six-minute walk distance; SP - support pressure; $\mathrm{SpO}_{2}$ - peripheral oxygen saturation; TLC - total lung capacity; TM - thoracic maneuvers; TS - tracheal suctioning; VCCMV - volume-control continuous mandatory ventilation; VEBH - ventilatory exercises for bronchial hygiene; VC - vital capacity; VIPP - ventilation with intermittent positive pressure; VS - volume support; ZEEP - zero end expiratory pressure; WP - weaning protocol. 
Table 3. CONSORT Statement.

\begin{tabular}{|c|c|c|c|c|c|c|c|c|c|c|c|c|c|c|c|c|c|c|c|c|c|c|c|c|c|}
\hline \multirow[t]{2}{*}{ 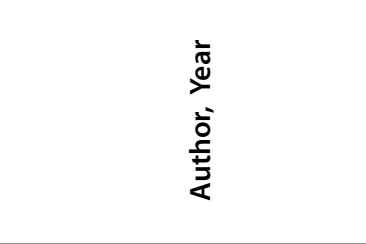 } & \multicolumn{2}{|c|}{ 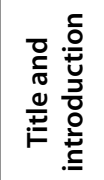 } & \multicolumn{10}{|c|}{$\begin{array}{l}\frac{n}{0} \\
\frac{0}{+} \\
\stackrel{0}{\Sigma}\end{array}$} & \multicolumn{7}{|c|}{$\begin{array}{l}\stackrel{\mathscr{\pm}}{5} \\
\stackrel{⿹}{\mathscr{y}}\end{array}$} & \multicolumn{3}{|c|}{ 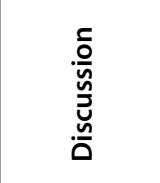 } & \multicolumn{3}{|c|}{ 㐫 } \\
\hline & 1 & 2 & 3 & 4 & 5 & 6 & 7 & 8 & 9 & 10 & 11 & 12 & 13 & 14 & 15 & 16 & 17 & 18 & 19 & 20 & 21 & 22 & 23 & 24 & 25 \\
\hline Al Jaaly et al. ${ }^{[17]}, 2013$ & A & $A$ & $A$ & $A$ & $A$ & A & A & $A$ & $A$ & $A$ & $A$ & $A$ & A & A & $A$ & A & $A$ & $A$ & A & $A$ & । & A & A & । & । \\
\hline Barros et al. ${ }^{[18]}, 2010$ & । & A & A & A & A & A & A & A & । & A & । & $A$ & । & । & । & । & A & । & । & A & । & A & । & । & । \\
\hline Blattner et al. ${ }^{[19]}, 2008$ & A & A & A & A & A & A & A & A & A & A & A & A & A & A & A & A & A & 1 & । & A & I & A & । & । & । \\
\hline Borges et al. ${ }^{[20]}, 2013$ & I & A & A & A & A & A & I & A & I & I & । & A & I & A & A & A & A & । & 1 & I & । & A & । & । & । \\
\hline Borghi-Silva et al..[21], 2005 & । & A & A & A & A & A & A & A & । & । & । & A & । & । & A & A & A & । & । & A & । & A & । & । & । \\
\hline Castellana et al.[22], 2003 & । & $A$ & । & $A$ & $A$ & $A$ & । & । & । & । & । & $A$ & । & । & $A$ & । & $A$ & $A$ & । & I & I & $A$ & । & । & । \\
\hline Celebi et al. ${ }^{[23]}, 2008$ & । & A & । & A & A & A & A & A & । & । & A & $A$ & । & । & A & A & A & । & । & A & । & A & । & । & । \\
\hline Crowe and Bradley ${ }^{[24]}, 1997$ & । & A & । & A & A & A & I & A & I & । & A & A & । & A & A & A & A & A & I & । & । & A & । & । & । \\
\hline Dongelmans et al. ${ }^{[25]}, 2009$ & A & A & A & A & $A$ & A & A & A & । & । & A & $A$ & । & $A$ & A & A & A & । & I & $A$ & । & A & । & । & । \\
\hline El-Kader[26], 2011 & 1 & A & I & A & A & A & I & I & 1 & I & I & A & I & I & A & I & A & 1 & A & I & I & A & I & I & I \\
\hline Ferreira et al..27], 2010 & । & A & A & A & A & A & I & I & I & I & I & A & I & । & A & A & A & । & । & A & A & A & । & I & A \\
\hline Franco et al. ${ }^{[28],} 2011$ & । & A & । & $A$ & A & A & । & । & । & । & । & । & । & । & । & A & A & । & । & । & । & A & । & । & । \\
\hline Garcia and Costa ${ }^{[29]}, 2002$ & । & A & । & A & A & A & । & A & । & । & । & I & । & A & । & । & A & । & । & । & । & A & । & । & । \\
\hline Gust et al. ${ }^{[30]}, 1996$ & I & A & I & I & A & A & I & I & I & I & I & A & I & I & A & A & A & I & I & I & I & A & I & I & I \\
\hline Haefener et al. ${ }^{[31]}, 2008$ & 1 & A & A & A & A & A & A & A & 1 & 1 & A & A & A & I & A & A & A & I & A & A & I & A & I & I & A \\
\hline Hendrix et al.[32], 2006 & A & A & 1 & 1 & A & A & A & A & 1 & 1 & 1 & A & 1 & A & A & A & A & 1 & 1 & A & 1 & A & 1 & 1 & 1 \\
\hline Herdy et al. ${ }^{[33]}, 2008$ & A & A & I & $A$ & $A$ & A & A & I & । & I & A & A & I & A & A & A & A & । & । & I & । & A & । & । & । \\
\hline Hirschhorn et al. ${ }^{[34]}, 2008$ & A & A & A & A & A & A & A & A & A & A & A & A & A & $A$ & A & A & A & । & A & A & । & A & । & । & । \\
\hline Jenkins et al..[35], 1989 & I & A & A & I & A & A & I & I & I & I & A & A & I & I & A & A & A & I & I & I & । & A & I & । & A \\
\hline Johnson et al.[36], 1995 & 1 & A & I & A & A & A & I & I & I & I & A & A & A & A & A & I & A & I & । & I & I & A & I & I & 1 \\
\hline Marvel et al. ${ }^{[37]}, 1986$ & । & A & I & 1 & A & A & I & A & I & 1 & A & A & 1 & A & A & I & A & 1 & । & I & 1 & A & 1 & I & I \\
\hline Matheus et al. ${ }^{[38]}, 2012$ & । & A & I & A & A & A & I & A & । & । & । & $A$ & I & A & A & A & A & I & I & $A$ & । & A & I & I & । \\
\hline Matte et al. ${ }^{[39]}, 2000$ & । & A & । & । & A & A & । & । & । & । & A & A & । & । & A & । & A & । & । & । & I & A & । & । & । \\
\hline Mendes et al. ${ }^{[40]}, 2010$ & A & A & A & I & A & A & A & A & 1 & I & I & A & A & I & A & A & A & । & A & A & 1 & A & I & I & । \\
\hline Michalopoulos et al.[41], 1998 & । & A & । & A & A & A & A & । & । & । & I & A & I & । & A & I & A & I & । & । & । & A & I & । & । \\
\hline Muller et al. ${ }^{[42]}, 2006$ & 1 & A & A & A & A & A & I & I & 1 & I & I & A & 1 & A & A & A & A & 1 & 1 & 1 & I & A & I & I & 1 \\
\hline Oikkonen et al..43], 1991 & I & A & 1 & I & A & $A$ & I & I & I & I & $A$ & A & I & I & A & A & A & I & 1 & I & 1 & A & I & I & । \\
\hline Renault et al..44], 2009 & । & A & A & A & A & A & I & A & । & । & । & $A$ & I & । & A & A & A & । & । & । & । & A & । & I & । \\
\hline Richter Larsen et al. ${ }^{[45]}, 1995$ & A & A & I & I & A & A & I & I & I & I & A & A & I & I & I & I & A & I & A & I & 1 & A & I & I & । \\
\hline Romanini et al.[46], 2007 & । & $A$ & I & A & A & A & । & $A$ & I & । & I & A & I & A & । & । & $A$ & । & । & $A$ & । & $A$ & । & I & A \\
\hline Savci et al.[47], 2011 & A & A & I & 1 & A & A & A & A & 1 & 1 & I & A & A & I & A & A & A & I & 1 & A & 1 & A & I & I & 1 \\
\hline Savci et al. ${ }^{[48]}, 2006$ & I & $A$ & I & $A$ & A & $A$ & I & । & I & I & $A$ & $A$ & I & $A$ & $A$ & $A$ & $A$ & I & 1 & । & 1 & $A$ & I & I & I \\
\hline Stein et al. ${ }^{[49]}, 2009$ & । & A & A & $A$ & $A$ & A & A & A & । & । & A & $A$ & $A$ & । & A & A & A & । & A & $A$ & । & A & A & । & A \\
\hline Stiller et al.[50], 1994 & 1 & A & 1 & A & $A$ & A & I & $A$ & 1 & I & A & A & I & I & $A$ & A & $A$ & 1 & 1 & 1 & 1 & $A$ & I & I & 1 \\
\hline Sulzer et al.[51], 2001 & । & A & । & A & A & A & 1 & I & 1 & 1 & । & A & 1 & A & A & A & A & 1 & 1 & A & 1 & A & I & I & 1 \\
\hline Thomas et al. ${ }^{[52]}, 1992$ & 1 & A & 1 & I & A & A & 1 & I & 1 & 1 & 1 & A & 1 & 1 & A & 1 & A & 1 & 1 & I & I & A & I & 1 & 1 \\
\hline Westerdahl et al. ${ }^{[53]}, 2001$ & 1 & $A$ & । & । & $A$ & $A$ & । & $A$ & 1 & । & A & $A$ & I & 1 & $A$ & $A$ & $A$ & । & । & । & I & $A$ & । & । & । \\
\hline Westerdahl et al. ${ }^{[54]}, 2005$ & I & A & । & A & A & A & A & । & । & । & $A$ & A & I & । & A & A & A & । & । & I & । & A & । & । & A \\
\hline Westerdahl et al. ${ }^{[55]}, 2003$ & । & A & I & $A$ & $A$ & A & । & । & । & । & A & A & । & I & A & A & A & । & I & । & I & A & । & । & । \\
\hline
\end{tabular}


Table 4. Extension of CONSORT Statement.

\begin{tabular}{|c|c|c|c|c|c|c|c|c|c|c|c|c|c|c|c|c|}
\hline \multirow{2}{*}{ Author, Year } & \multirow{2}{*}{$\begin{array}{c}\text { Title and } \\
\text { abstract }\end{array}$} & \multicolumn{10}{|c|}{ Methods } & \multicolumn{3}{|c|}{ Results } & \multicolumn{2}{|c|}{ Discussion } \\
\hline & & 2 & 3 & 4 & 5 & 6 & 7 & 8 & 9 & 10 & 11 & 12 & 13 & 14 & 15 & 16 \\
\hline Al Jaaly et al. ${ }^{[17]}, 2013$ & । & A & A & $A$ & $A$ & I & A & $A$ & I & । & A & A & $A$ & A & । & I \\
\hline Barros et al. ${ }^{[18]}, 2010$ & 1 & A & A & $A$ & I & I & A & A & I & 1 & A & 1 & A & I & I & I \\
\hline Blattner et al.. ${ }^{[19]}, 2008$ & 1 & A & A & A & A & । & A & A & A & A & A & A & A & A & 1 & । \\
\hline Borges et al. ${ }^{[20]}, 2013$ & 1 & A & A & $A$ & I & I & I & $A$ & I & । & A & I & $A$ & A & । & I \\
\hline Borghi-Silva et al.[21], 2005 & 1 & A & A & A & A & । & 1 & A & । & I & A & I & A & A & 1 & I \\
\hline Castellana et al.[22], 2003 & I & A & A & A & I & I & I & I & । & I & A & I & A & A & I & I \\
\hline Celebi et al. ${ }^{[23]}, 2008$ & I & $A$ & $A$ & $A$ & I & । & $A$ & $A$ & A & । & A & । & $A$ & $A$ & । & I \\
\hline Crowe and Bradley ${ }^{[24]}, 1997$ & I & A & A & A & A & I & 1 & A & A & I & A & I & A & A & 1 & 1 \\
\hline Dongelmans et al.[25], 2009 & I & A & A & A & A & I & A & A & A & । & A & । & A & A & I & । \\
\hline El-Kader ${ }^{[26]}, 2011$ & I & A & A & A & I & 1 & 1 & 1 & I & I & A & I & A & A & I & I \\
\hline Ferreira et al.[27], 2010 & । & A & A & A & । & । & I & । & । & । & A & । & A & A & 1 & । \\
\hline Franco et al. ${ }^{[28]}, 2011$ & I & A & A & A & । & । & । & । & । & । & 1 & । & A & 1 & 1 & । \\
\hline Garcia and Costa ${ }^{[29]}, 2002$ & I & A & A & A & I & I & I & A & I & I & A & I & A & I & I & I \\
\hline Gust et al. ${ }^{[30]}, 1996$ & I & A & A & A & A & I & I & I & 1 & 1 & A & I & A & A & 1 & I \\
\hline Haefener et al.[31], 2008 & I & A & A & A & A & I & A & A & A & । & $A$ & A & A & A & 1 & I \\
\hline Hendrix et al.[32], 2006 & 1 & A & $A$ & $A$ & A & I & $A$ & $A$ & I & I & A & I & $A$ & A & 1 & I \\
\hline Herdy et al. ${ }^{[33]}, 2008$ & । & A & A & A & A & I & A & I & A & I & A & I & A & A & 1 & I \\
\hline Hirschhorn et al. ${ }^{[34]}, 2008$ & । & A & A & A & A & । & A & A & A & A & A & A & A & A & 1 & । \\
\hline Jenkins et al..[35], 1989 & I & $A$ & $A$ & $A$ & I & । & I & I & $A$ & । & $A$ & I & $A$ & $A$ & । & I \\
\hline Johnson et al. ${ }^{[36],} 1995$ & I & A & $A$ & $A$ & I & I & । & I & A & I & $A$ & A & $A$ & A & 1 & I \\
\hline Marvel et al. ${ }^{[37]}, 1986$ & 1 & A & A & A & A & I & । & A & A & । & $A$ & । & A & A & 1 & I \\
\hline Matheus et al. ${ }^{[38]}, 2012$ & I & A & A & $A$ & I & I & I & $A$ & I & । & A & I & $A$ & $A$ & I & I \\
\hline Matte et al. ${ }^{[39]}, 2000$ & I & A & $A$ & A & I & I & I & I & A & I & A & I & A & A & 1 & I \\
\hline Mendes et al..40], 2010 & I & A & A & A & । & । & A & A & । & । & A & A & A & A & 1 & । \\
\hline Michalopoulos et al..41], 1998 & I & A & $A$ & $A$ & $A$ & I & A & I & I & । & A & I & $A$ & A & । & I \\
\hline Muller et al. ${ }^{[42]}, 2006$ & 1 & A & A & A & 1 & 1 & 1 & I & 1 & 1 & A & 1 & A & A & 1 & 1 \\
\hline Oikkonen et al.[43], 1991 & 1 & A & A & A & I & I & I & I & A & I & A & I & A & A & 1 & I \\
\hline Renault et al. ${ }^{[44]}, 2009$ & 1 & A & A & A & I & । & I & A & । & । & A & । & A & A & 1 & । \\
\hline Richter Larsen et al. ${ }^{[45]}, 1995$ & । & A & A & A & । & । & 1 & । & A & 1 & A & । & A & । & । & । \\
\hline Romanini et al.[46], 2007 & 1 & A & A & $A$ & I & । & । & A & I & । & A & । & $A$ & । & । & I \\
\hline Savci et al. ${ }^{[47]}, 2011$ & I & A & $A$ & $A$ & A & I & A & A & I & I & A & $A$ & $A$ & $A$ & I & I \\
\hline Savci et al. ${ }^{[48]}, 2006$ & I & A & A & A & A & I & । & I & A & । & A & I & A & A & । & 1 \\
\hline Stein et al. ${ }^{[49]}, 2009$ & I & A & A & A & I & I & A & A & A & । & $A$ & A & A & A & 1 & I \\
\hline Stiller et al. ${ }^{[50]}, 1994$ & I & A & A & A & I & I & I & $A$ & A & । & A & I & $A$ & $A$ & I & I \\
\hline Sulzer et al. ${ }^{[51]}, 2001$ & I & A & A & A & A & । & 1 & । & । & I & A & I & A & A & । & 1 \\
\hline Thomas et al.[52], 1992 & I & A & A & A & I & I & । & I & । & । & $A$ & I & A & A & 1 & I \\
\hline Westerdahl et al. ${ }^{[53]}, 2001$ & 1 & A & A & A & I & I & I & A & A & । & A & । & $A$ & A & 1 & I \\
\hline Westerdahl et al. ${ }^{[54]}, 2005$ & I & A & A & A & I & 1 & A & । & A & । & A & । & $A$ & A & 1 & I \\
\hline Westerdahl et al. ${ }^{[55],} 2003$ & । & A & A & A & A & । & 1 & I & A & । & A & । & A & A & । & । \\
\hline
\end{tabular}

A - adequate; I - inadequate. 
Table 5. Risk of bias.

\begin{tabular}{|c|c|c|c|c|c|c|}
\hline Author, Year & $\begin{array}{l}\text { Adequate } \\
\text { sequence } \\
\text { generation }\end{array}$ & $\begin{array}{l}\text { Allocation } \\
\text { concealment }\end{array}$ & $\begin{array}{l}\text { Blinding of } \\
\text { patients and } \\
\text { investigators }\end{array}$ & $\begin{array}{c}\text { Blinding of } \\
\text { outcome } \\
\text { assessors }\end{array}$ & $\begin{array}{l}\text { Description } \\
\text { of losses and } \\
\text { exclusions }\end{array}$ & $\begin{array}{c}\text { Intention-to-treat } \\
\text { analysis }\end{array}$ \\
\hline Al Jaaly et al..[17], 2013 & Yes & Yes & No & Yes & Yes & Yes \\
\hline Barros et al. ${ }^{[18]}, 2010$ & Yes & No & No & No & Yes & No \\
\hline Blattner et al. ${ }^{[19]}, 2008$ & Yes & Yes & No & Yes & Yes & Yes \\
\hline Borges et al. ${ }^{[20]}, 2013$ & Yes & No & No & No & Yes & No \\
\hline Borghi-Silva et al. ${ }^{[21]}, 2005$ & Yes & No & No & No & Yes & No \\
\hline Castellana et al. ${ }^{[22]}, 2003$ & No & No & No & No & No & Not report \\
\hline Celebi et al. ${ }^{[23]}, 2008$ & Yes & No & No & Yes & No & Not report \\
\hline Crowe and Bradley ${ }^{[24]}, 1997$ & Yes & No & No & Yes & No & Not report \\
\hline Dongelmans et al..25], 2009 & Yes & No & Yes & No & Yes & No \\
\hline El-Kader ${ }^{[26]}, 2011$ & No & No & No & No & No & Not report \\
\hline Ferreira et al. ${ }^{[27]}, 2010$ & No & No & No & No & No & Not report \\
\hline Franco et al.[28], 2011 & No & No & No & No & No & Not report \\
\hline Garcia and Costa ${ }^{[29],} 2002$ & No & No & No & No & Yes & No \\
\hline Gust et al.[30], 1996 & No & No & No & No & No & Not report \\
\hline Haefener et al. ${ }^{[31]}, 2008$ & Yes & No & No & Yes & Yes & Yes \\
\hline Hendrix et al. ${ }^{[32],} 2006$ & Yes & No & No & No & No & Not report \\
\hline Herdy et al. ${ }^{[33]}, 2008$ & No & No & No & Yes & Yes & Yes \\
\hline Hirschhorn et al. ${ }^{[34]}, 2008$ & Yes & Yes & Yes & Yes & Yes & Yes \\
\hline Jenkins et al. ${ }^{[35]}, 1989$ & No & No & Yes & No & Yes & No \\
\hline Johnson et al. ${ }^{[36]}, 1995$ & No & No & No & Yes & Yes & No \\
\hline Marvel et al. ${ }^{[37]}, 1986$ & Yes & No & No & Yes & Yes & No \\
\hline Matheus et al. ${ }^{[38],} 2012$ & Yes & No & No & No & No & Not report \\
\hline Matte et al. ${ }^{[39]}, 2000$ & No & No & No & Yes & Yes & No \\
\hline Mendes et al. ${ }^{[40]}, 2010$ & Yes & No & No & No & Yes & No \\
\hline Michalopoulos et al.[41], 1998 & No & No & No & No & Yes & No \\
\hline Muller et al. ${ }^{[42],} 2006$ & No & No & No & No & No & Not report \\
\hline Oikkonen et al.[43], 1991 & No & No & No & Yes & Yes & No \\
\hline Renault et al. ${ }^{[44]}, 2009$ & Yes & No & No & No & Yes & No \\
\hline Richter Larsen et al.. ${ }^{[45]}, 1995$ & No & No & No & Yes & Yes & No \\
\hline Romanini et al.[46], 2007 & Yes & No & No & No & No & Not report \\
\hline Savci et al.[47], 2011 & Yes & No & No & No & Yes & No \\
\hline Savci et al.[48], 2006 & No & No & No & Yes & No & Not report \\
\hline Stein et al. ${ }^{[49]}, 2009$ & Yes & No & No & Yes & Yes & No \\
\hline Stiller et al. ${ }^{[50]}, 1994$ & Yes & No & No & Yes & Yes & No \\
\hline Sulzer et al. ${ }^{[51]}, 2001$ & No & No & No & No & Yes & No \\
\hline Thomas et al. ${ }^{[52],} 1992$ & No & No & No & No & No & Not report \\
\hline Westerdahl et al.[53], 2001 & Yes & No & No & Yes & Yes & No \\
\hline Westerdahl et al. ${ }^{[54]}, 2005$ & No & No & No & Yes & Yes & No \\
\hline Westerdahl et al.[55], 2003 & No & No & No & Yes & Yes & No \\
\hline
\end{tabular}




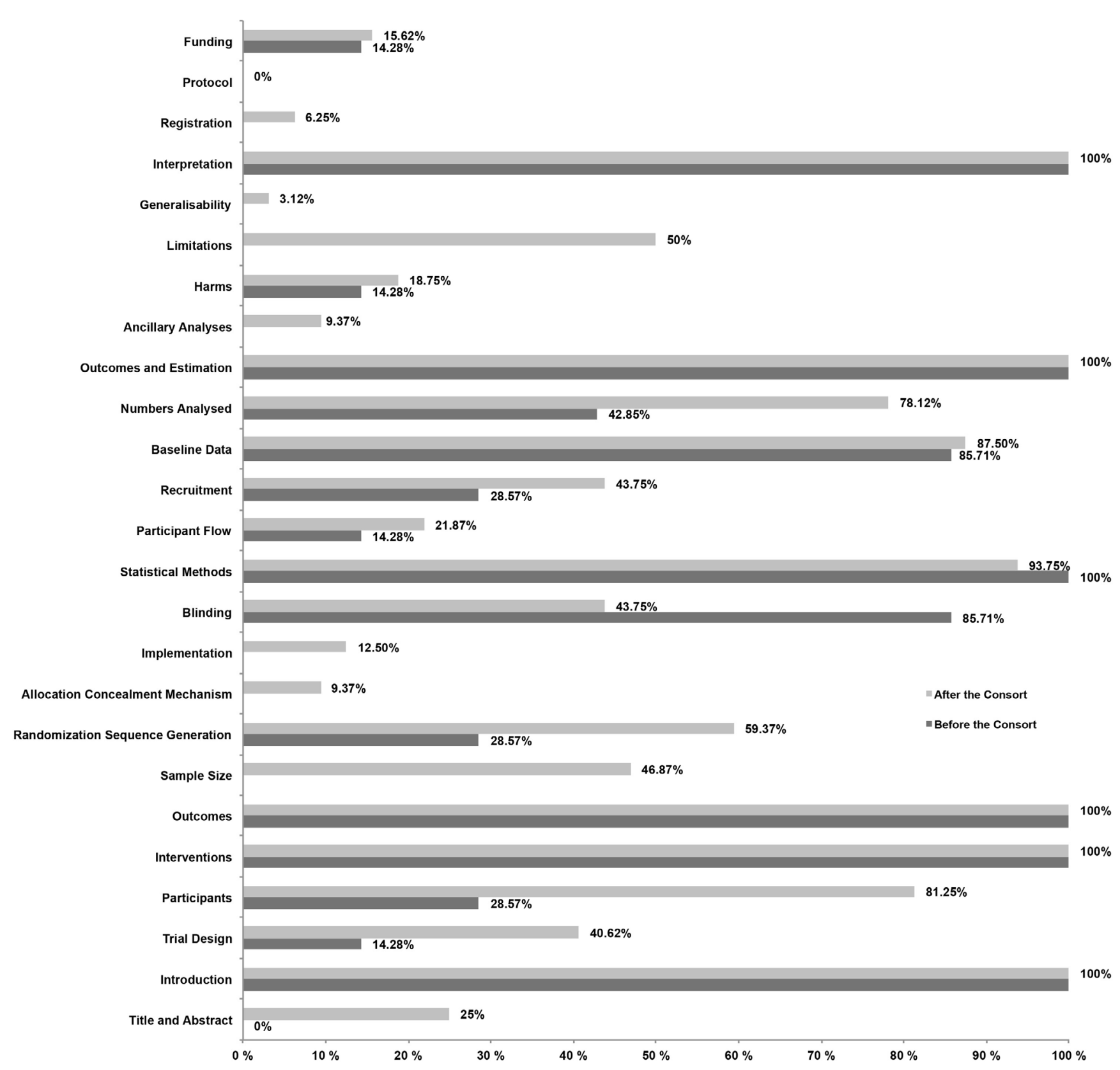

Fig. 2 - Comparison studies published before and after the CONSORT Statement.

\section{DISCUSSION}

The development of research related to the assessment of the methodological quality of scientific production in health, especially in physiotherapy, is still of little expression. Therefore, this is the first systematic review that has assessed the methodological quality of RCT of physiotherapy treatment in postoperative patients of CABG in the ICU based on the instruments CONSORT Statement, its extension for nonpharmacologic treatment interventions and the Cochrane Collaboration's tool for assessing risk of bias.
In general, over the years, the methodological quality of studies has increased, especially if we set as a cutoff the year of publication of the CONSORT Statement checklist. Among the checklist's 25 items, five have remained with an equal adequacy rate and 17 have been more broadly documented. Geha et al. ${ }^{[10]}$ when assessing the quality of cardiorespiratory physiotherapy studies, found similar results, with a rising curve of quality assessed through the PEDro scale. In a study published by Hopewell et al.[56], in which the quality of trials indexed by the PubMed published between 2000 and 2006 were evaluated, the results were very similar. While the quality of the studies had

\section{4}




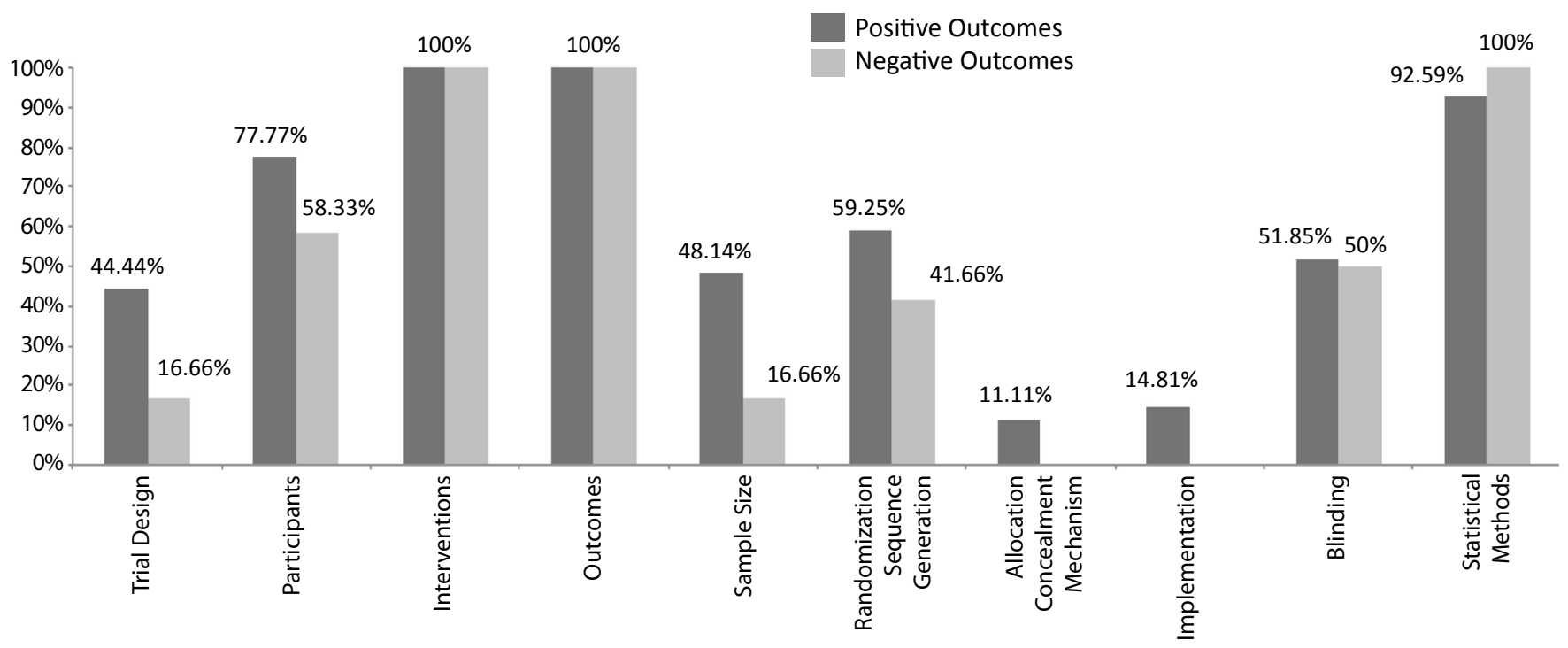

Fig. 3 - Methods section of CONSORT: comparison studies with positive and negative outcomes.

improved over time, it was still below an acceptable level (for example, only $45 \%$ of the trials had included a calculation of the sample size). This suggests that, despite the release of the CONSORT Statement over the last decade, a large proportion of authors, reviewers and journal editors have not yet implemented these recommendations.

The two items that showed an adequacy decline were statistical methods and blinding. The first demonstrated a difference smaller than 7\% (two studies), being therefore irrelevant. In studies published after the CONSORT, a reduction of the reporting of blinding in $41.96 \%$ of the studies was observed, and only $43.75 \%$ informed that blinding was performed in their methodology, with no further details. When the evaluation was directed at whom was blinded (patient, investigators or outcome assessor), the adequacy was even lower, reaching $7.69 \%$. Our results are similar to the studies ${ }^{[8-11]}$ who assessed the quality of studies in the areas of cardiothoracic, neurological, sports and aquatic physiotherapy, respectively. Research indicates that blinding, or lack thereof, is associated with a greater tendency to maximize the treatment's effect ${ }^{[57-61]}$. In a study by Boutron et al. ${ }^{[62]}$, in which pharmacologic and non-pharmacologic treatments for hip or knee osteoarthritis were compared, blinding was found to be less frequent in nonpharmacologic studies, even when there is a possibility to do it. It should be emphasized that an adequate methodological conduct in relation to blinding results in a higher number of professionals involved and often adds costs to the research, which becomes a limiting factor. The lack of blinding interferes directly on the results, making both its internal and external validity look dubious. Consequently, the use of these studies in systematic reviews becomes limited, generating biased results.

Due to the large number of publications, the standardization of papers to the rules of each journal must be followed, which mainly includes a limit for the number of words, tables and figures. For this reason, very precise details of the research development may end up without space. Given this reality, none of the papers included in this review presented the items title and abstract, assessment of adherence to the protocol, interpretation, and generalizability as required by the CONSORT extension for non-pharmacologic treatment interventions. However, these undescribed data may have been part of the research development, but they were not disclosed. Specifically, there is no available information in the literature for us to corroborate such finding. A combination of techniques was present in $69.23 \%$ of the studies. This result is in accordance with a systematic review published by Stiller ${ }^{[63]}$ on physiotherapy performance in the ICU. It was not possible to evaluate the effectiveness of each technique alone, the same way as the large heterogeneity of methodologies and samples made it impossible to carry out a statistical analysis.

Another interesting finding of our research was that the 27 studies with positive outcomes demonstrated a better quality regarding the 10 items of CONSORT Methods section. Except for the statistical methods, in which the difference was of only $7 \%$, all other items were appropriately described more often in studies with positive outcomes. Beckerman et al. ${ }^{[64]}$, when evaluating laser therapy in different musculoskeletal and dermatological conditions, found similar results, with studies with positive outcomes having better quality. A year later, the same author found contrary results when assessing the effectiveness of physiotherapy in musculoskeletal disorders ${ }^{[65]}$. Studies with negative outcomes tend to be submitted less frequently, with a lower acceptance by journal reviewers. Therefore, there may be an overestimation of treatment effects, leading to important implications in choosing the best treatment to follow.

The gap between the publication of the results of a scientific research and its actual implementation in the professional routine is still substantial, leading to health care practices of levels lower than expected ${ }^{[66]}$. However, prior to this, the research planning and development should be improved so that its 
results are as close as possible to the truth and are legitimized by a methodology of quality.

\section{Limitation of the Study}

A limitation of this systematic review is that literature search was not conducted in Embase database.

\section{CONCLUSION}

The description of the necessary items for the correct execution, conduction and publication of studies has increased over the years, but it still has great scope for improvement. In general, the methodological quality is below an acceptable level in order to obtain results that are reliable and applicable in the daily practice.

\section{Authors' roles \& responsibilities}

JL Conception and design of the work; acquisition, analysis, interpretation of data for the work; drafting the work and revising it critically for important intellectual content; final approval of the version to be published

CS

Conception and design of the work; acquisition, analysis, interpretation of data for the work; drafting the work and revising it critically for important intellectual content; final approval of the version to be published

RDMP Conception and design of the work; acquisition, analysis, interpretation of data for the work; drafting the work and revising it critically for important intellectual content; final approval of the version to be published

\section{REFERENCES}

1. Altman DG, Schulz KF, Moher D, Egger M, DavidoffF, Elbourne D, et al. The revised CONSORT statement for reporting randomized trials: explanation and elaboration. Ann Intern Med. 2001;134(8):663-94.

2. Schriger DL, Arora S, Altman DG. The content of medical journal instructions for authors. Ann Emer Med. 2006;48(6):743-9.

3. Carvalho APV, Silva V, Grande AJ. Avaliação do risco de viés de ensaios clínicos randomizados pela ferramenta da colaboração Cochrane. Diagn Tratamento. 2013;18(1):38-44.

4. Carvalho T, Cortez AA, Ferraz A, Nóbrega ACL, Brunetto AF, Herdy AH, et al. Diretriz de reabilitação cardiopulmonar e metabólica: aspectos práticos e responsabilidades. Arq Bras Cardiol. 2006;86(1):74-82.

5. Renault JA, Costa-Val R, Rossetti MB. Fisioterapia respiratória na disfunção pulmonar pós-cirurgia cardíaca. Rev Bras Cir Cardiovasc. 2008;23(4):562-9.

6. Padovani C, Cavenaghi OM. Recrutamento alveolar em pacientes no pós-operatório imediato de cirurgia cardíaca. Rev Bras Cir Cardiovasc. 2011;26(1):116-21.

7. Dannapfel P, Peolsson A, Nilsen P.What supports physiotherapist's use of research in clinical practice? A qualitative study in Sweden. Implement Sci. 2013:8:31

8. Moseley A, Sherrington C, Herbert R, Maher C. The extent and quality of evidence in neurological physiotherapy: an analysis of the Physiotherapy Evidence Database (PEDro). Brain Impair. 2000;1 (2):130-40.

9. Sherrington C, Moseley AM, Herbert RD, Elkins MR, Maher CG. Ten years of evidence to guide physiotherapy interventions: Physiotherapy Evidence Database (PEDro). Br J Sports Med. 2010;44(12):836-7.

10. Geha NN, Moseley AM, Elkins MR, Chiavegato LD, Shiwa SR, Costa LO. The quality and reporting of randomized trials in cardiothoracic physical therapy could be substantially improved. Respir Care. 2013;58(11):1899-906.

11. Gimenes RO, Fontes SV, Fukujima MM, Matas SLA, Prado GF. Análise crítica de ensaios clínicos aleatórios sobre fisioterapia aquática para pacientes neuroológicos. Rev Neurociências. 2005;13(1):5-10.

12. Higgins JPT, Green S. (editors). Cochrane handbook for systematic reviews of interventions Version 5.1.0 [updated March 2011]. The Cochrane Collaboration, 2011. Available from: www.cochrane-handbook.org.

13. Moher D, Liberati A, Tetzlaff J, Altman DG; PRISMA Group. Preferred reporting items for systematic reviews and meta-analyses: the PRISMA statement. PLoS Med. 2009;6(7):e1000097.

14. Moher D, Hopewell S, Schulz KF, Montori V, Gotzsche PC, Deveraux PJ, et al. CONSORT 2010 explanation and elaboration: updated guidelines for reporting parallel group randomised trials. BMJ. 2010;340:c869.

15. Boutron I, Moher D, Altman DG, Schulz KF, Ravaud P; CONSORT Group. Extending the CONSORT statement to randomized trials of nonpharmacologic treatment: explanation and elaboration. Ann Intern Med. 2008;148(4):295-309.

16. Robinson KA, Dickersin K. Development of a highly sensitive search strategy for the retrieval of reports of controlled trials using PubMed. Int J Epidemiol. 2002;31(1):150-3.

17. Al Jaaly E, Fiorentino F, Reeves BC, Ind PW, Angelini GD, Kemp S, et al. Effect of adding postoperative noninvasive ventilation to usual care to prevent pulmonary complications in patients undergoing coronary artery bypass grafting: a randomized controlled trial. JThorac Cardiovasc Surg. 2013;146(4):912-8.

18. Barros GF, Santos CS, Granado FB, Costa PT, Limaco RP, Gardenghi G. Treinamento muscular respiratório na revascularização do miocárdio. Rev Bras Cir Cardiovasc. 2010;25(4):483-90.

19. Blattner C, Guaragna JC, Saadi E. Oxygenation and static compliance is improved immediately after early manual hyperinflation following myocardial revascularisation: a randomised controlled trial. Aust J Physiother. 2008;54(3):173-8.

20. Borges DL, Nina VJ, Costal MA, BaldezTE, Santos NP, Lima IM, et al. Effects of different PEEP levels on respiratory mechanics and oxygenation after coronary artery bypass grafting. Rev Bras Cir Cardiovasc. 2013;28(3):380-5.

21. Borgui-Silva A, Mendes RG, Costa FS, Di Lorenzo VA, Oliveira CR, Luzzi $S$. The influences of positive end expiratory pressure (PEEP) associated wth physiotherapy intervention in phase I cardiac rehabilitation. Clinics (Sao Paulo). 2005;60(6):465-72.

22. Castellana FB, Malbouisson LMS, Carmona MJC, Lopes CR, Auler Júnior JOC. Comparação entre ventilação controlada a volume e a pressão no tratamento da hipoxemia no período pós-operatório de cirurgia de revascularização do miocárdio. Rev Bras Anestesiol. 2003;53(4):440-8.

23. Celebi S, Köner O, Menda F, Omay O, Günay I, Suzer K, et al. Pulmonary effects of noninvasive ventilation combined with the recruitment maneuver after cardiac surgery. Anesth Analg. 2008;107(2):614-9.

24. Crowe JM, Bradley CA. The effectiveness of incentive spirometry with physical therapy for high-risk patients after coronary artery bypass surgery. Phys Ther. 1997;77(3):260-8.

25. Dongelmans DA, Veelo DP, Paulus F, de Mol BA, Korevaar JC, Kudoga A, et al. Weaning automation with adaptive support ventilation: a randomized controlled trial in cardiothoracic surgery patients. Anesth Analg. 2009;108(2):565-71.

26. El-Kader SMA. Blood gases response to different breathing modalities in phase I of cardiac rehabilitation program after coronary artery bypass graft. Eur J Gen Med. 2011;8(2):85-9.

27. Ferreira GM, Haeddner MP, Barreto SSM, Dall'ago P. Espirometria de incentivo com pressão positiva expiratória é benéfica após revascularização miocárdio. Arq Bras Cardiol. 2010;94(2):246-51. 
28. Franco AM, Torres FCC, Simon ISL, Morales D, Rodrigues AJ. Avaliação da ventilação não-invasiva com dois níveis de pressão positiva nas vias aéreas após cirurgia cardíaca. Rev Bras Cir Cardiovasc. 2011;26(4):582-90.

29. Garcia RCP, Costa D. Treinamento muscular respiratório em pós-operatório de cirurgia cardíaca eletiva. Rev Bras Fisioter. 2002;6(3):139-46.

30. Gust R, Gottschalk A, Schmidt H, Böttiger BW, Böhrer H, Martin E. Effects of continuous (CPAP) and bi-level positive airway pressure (BiPAP) on extravascular lung water after extubation of the trachea in patients following coronary artery bypass grafting. Intensive Care Med. 1996;22(12):1345-50.

31. Haeffener MP, Ferreira GM, Barreto SS, Arena R, Dall'Ago P. Incentive spirometry with expiratory positive airway pressure reduces pulmonary complications, improves pulmonary function and 6-minute walk distance in patients undergoing coronary artery bypass graft surgery. Am Heart J. 2008;156(5):900.

32. Hendrix H, Kaiser ME, Yusen RD, Merk J. A randomized trial of automated versus conventional protocol-driven weaning from mechanical ventilation following coronary artery bypass surgery. Eur J Cardiothorac Surg. 2006;29(6):957-63.

33. Herdy AH, Marcchi PL, Vila A, Tavares C, Collaço J, Niebauer J, et al. Pre- and postoperative cardiopulmonary rehabilitation in hospitalized patients undergoing coronary artery bypass surgery: a randomized controlled trial. Am J Phys Med Rehabil. 2008;87(9):714-9.

34. Hirschhorn AD, Richards D, Mungovan SF, Morris NR, Adams L. Supervised moderate intensity exercise improves distance walked at hospital discharge following coronary artery bypass graft surgery: a randomised controlled trial. Heart Lung Circ. 2008;17(2):129-38.

35. Jenkins SC, Soutar SA, Loukota JM, Johnson LC, Moxham J. Physiotherapy after coronary artery surgery: are breathing exercises necessary? Thorax. 1989;44(8):634-9.

36. Johnson D, Kelm C, To T, Hurst T, Naik C, Gulka I, et al. Postoperative physical therapy after coronary artery bypass surgery. Am J Respir Crit Care Med. 1995;152(3):953-8.

37. Marvel SL, Elliott CG, Tocino I, Greenway LW, Metcalf SM, Chapman $\mathrm{RH}$. Positive end-expiratory pressure following coronary artery bypass grafting. Chest. 1986;90(4):537-41.

38. Matheus GB, Dragosavac D, Trevisan P, Costa CE, Lopes MM, Ribeiro GCA. Treinamento muscular melhora o volume corrente e a capacidade vital no pós-operatório de revascularização do miocárdio. Rev Bras Cir Cardiovasc. 2012;27(3):362-9.

39. Matte P, Jacquet L, Van Dyck M, Goenen M. Effects of conventional physiotherapy, continuous positive airway pressure and non-invasive ventilatory support with bilevel positive airway pressure after coronary artery bypass grafting. Acta Anaesthesiol Scand. 2000;44(1):75-81.

40. Mendes RG, Simões RP, De Souza Melo Costa F, Pantoni CB, Di Thommazo L, Luzzi S, et al. Short-term supervised inpatient physiotherapy exercise protocol improves cardiac autonomic function after coronary artery bypass graft surgery: a randomised controlled trial. Disabil Rehabil. 2010;32(16):1320-7.

41. Michalopoulos A, Anthi A, Rellos K, Geroulanos S. Effects of positive end-expiratory pressure (PEEP) in cardiac surgery patients. Respir Med. 1998;92(6):858-62.

42. Müller AP, Olandoski M, Macedo R, Costantini C, Guarita-Souza LC. Estudo comparativo entre a pressão positiva intermitente (reanimador de Müller) e contínua no pós-operatório de cirurgia de revascularização do miocárdio. Arq Bras Cardiol. 2006;86(3):232-9.

43. Oikkonen M, Karjalainen K, Kähärä V, Kuosa R, Schavikin L. Comparison of incentive spirometry and intermittent positive pressure breathing after coronary artery bypass graft. Chest. 1991;99(1):60-5.

44. Renault JA, Costa-Val R, Rossetti MB, Neto MH. Comparação entre exercícios de respiração profunda e espirometria de incentivo no pósoperatório de cirurgia de revascularização do miocárdio. Rev Bras Cir Cardiovasc. 2009;24(2):165-72.

45. Richter Larsen K, Ingwersen U, Thode S, Jakobsen S. Mask physiotherapy in patients after heart surgery: a controlled study. Intensive Care Med. 1995;21(6):469-74.

46. RomaniniW, Muller AP, Carvalho KAT, Olandoski M, Faria-Neto JR, Mendes $\mathrm{FL}$, et al. Os efeitos da pressão positiva intermitente e do incentivador respiratório no pós-operatório de revascularização miocárdica. Arq Bras Cardiol. 2007; 89(2):105-10.

47. Savci S, Degirmenci B, Saglam M, Arikan H, Inal-Ince D, Turan HN, et al. Short-term effects of inspiratory muscle training in coronary artery bypass graft surgery: a randomized controlled trial. Scand Cardiovasc J. 2011;45(5):286-93.

48. Savci S, Sakinç S, Inal-Ince DI, Kuralay E. Active cycle of breathing techniques and incentive spirometer in coronary artery bypass graft surgery. Fizyoterapi Rehabilitasyon. 2006;17(2):61-9.

49. Stein R, Maia CP, Silveira AD, Chiappa GR, Myers J, Ribeiro JP. Inspiratory muscle strength as a determinant of functional capacity early after coronary artery bypass graft surgery. Arch Phys Med Rehabil. 2009;90(10):1685-91.

50. Stiller K, Montarello J, Wallace M, Daff M, Grant R, Jenkins S, et al. Efficacy of breathing and coughing exercises in the prevention of pulmonary complications after coronary artery surgery. Chest. 1994;105(3):741-7.

51. Sulzer CF, Chioléro R, Chassot PG, Mueller XM, Revelly JP. Adaptive support ventilation for fast tracheal extubation after cardiac surgery: a randomized controlled study. Anesthesiology. 2001;95(6):1339-45.

52. Thomas AN, Ryan JP, Doran BR, Pollard BJ. Nasal CPAP after coronary artery surgery. Anaesthesia. 1992;47(4):316-9.

53. Westerdahl E, Lindmark B, Almgren SO, Tenling A. Chest physiotherapy after coronary artery bypass graft surgery: a comparison of three different deep breathing techniques. J Rehabil Med. 2001;33(2):79-84.

54. Westerdahl E, Lindmark B, Eriksson T, Friberg O, Hedenstierna G, Tenling A. Deep-breathing exercises reduce atelectasis and improve pulmonary function after coronary artery bypass surgery. Chest. 2005;128(5):3482-8.

55. Westerdahl E, Lindmark B, Eriksson T, Hedenstierna G, Tenling. The immediate effects of deep breathing exercises on atelectasis and oxygenation after cardiac surgery. Scand Cardiovasc J. 2003;37(6):363-7.

56. Hopewell S, Dutton S, Yu LM, Chan AW, Altman DG. The quality of reports of randomised trials in 2000 and 2006: comparative study of articles indexed in PubMed. BMJ. 2010;340:c723.

57. Gluud LL. Bias in clinical intervention research. Am J Epidemiol. 2006;163(6):493-501.

58. Jüni P, Altman DG, Egger M. Systematic reviews in health care: assessing the quality of controlled clinical trials. BMJ. 2001;323(7303):42-6.

59. Kjaergard LL, Villumsen J, Gluud C. Reported methodologic quality and discrepancies between large and small randomized trials in meta-analyses. Ann Intern Med. 2001;135(11):982-9.

60. Moher D, Pham B, Jones A, Cook DJ, Jadad AR, Moher M, et al. Does quality of reports of randomised trials affect estimates of intervention efficacy reported in meta-analyses? Lancet. 1998;352(9128):609-13.

61. Schulz KF, Chalmers I, Hayes RJ, Altman DG. Empirical evidence of bias. Dimensions of methodological quality associated with estimates of treatment effects in controlled trials. JAMA. 1995;273(5):408-12.

62. Boutron I, Tubach F, Giraudeau B, Ravaud P. Blinding was judged more difficult to achieve and maintain in nonpharmacologic than pharmacologic trials. J Clin Epidemiol. 2004;57(6):543-50.

63. Stiller K. Physiotherapy in intensive care: an updated systematic review. Chest. 2013;144(3):825-47.

64. Beckerman H, de Bie RA, Bouter LM, De Cuyper HJ, Oostendorp RA. The efficacy of laser therapy for musculoskeletal and skin disorders: a criteria-based meta-analysis of randomized clinical trials. Phys Ther. 1992;72(7):483-91.

65. Beckerman H, Bouter LM, van der Heijden GJ, de Bie RA, Koes BW. Efficacy of physiotherapy for musculoskeletal disorders: what can we learn from research? Br J Gen Pract. 1993;43(367):73-7.

66. Ohtake PJ, Strasser DC, Needham DM. Translating research into clinical practice: the role of quality improvement in providing rehabilitation for people with critical illness. Phys Ther. 2013;93(2):128-33. 